\title{
DISCLAIMER
}

This report was prepared as an account of work sponsored by an agency of the United States Government. Neither the United States Government nor any agency thereof, nor any of their employees, makes any warranty, express or implied, or assumes any legal liability or responsibility for the accuracy, completeness, or usefulness of any information, apparatus, product, or process disclosed, or represents that its use would not infringe privately owned rights. Reference herein to any specific commercial product, process, or service by trade name, trademark, manufacturer, or otherwise does not necessarily constitute or imply its endorsement, recommendation, or favoring by the United States Government or any agency thereof. The views and opinions of authors expressed herein do not necessarily state or reflect those of the United States Government or any agency thereof.

\section{Characterization of Greater-Than-Class C Sealed Sources Volume 3: Sealed Sources Held by General Licensees}

\author{
Gerald Harris
}

September 1994

\section{Idaho National Engineering Laboratory \\ Idaho Falls, Idaho 83415}

\section{Prepared for the}

U.S. Department of Energy

Assistant Secretary for Environmental Management

Under DOE Idaho Operations Office

Contract DE-AC07-76ID01570

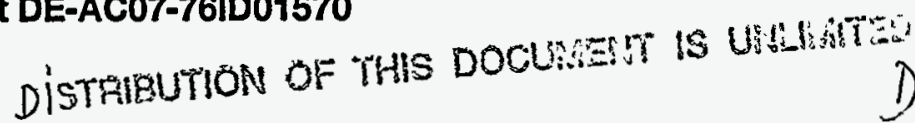




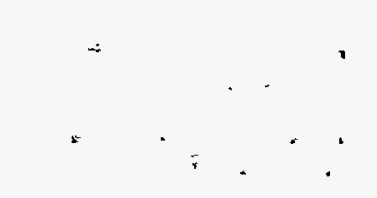




\section{DISCLAIMER}

Portions of this document may be illegible in electronic image products. Images are produced from the best available original document. 


\section{ABSTRACT}

This is the third volume in a series of three volumes characterizing the population of sealed sources that may become greater-than-Class $C$ low-level radioactive waste (GTCC LLW). In this volume, those sources possessed by general licensees are discussed.

General-licensed devices may contain sealed sources with significant amounts of radioactive material. However, the devices are designed to be safe to use without special knowledge of radiological safety practices. Devices containing Am-241 or Cm-244 sources are most likely to become GTCC LLW after concentration averaging.

This study estimates that there are about 16,000 GTCC devices held by general licensees; 15,000 of these contain Am-241 sources and 1,000 contain Cm-244 sources. Additionally, this study estimates that there are 1,600 GTCC devices sold to general licensees each year. However, due to a lack of available information on general licensees in Agreement States, these estimates are uncertain. This uncertainty is quantified in the low and high case estimates given in this report, which span approximately an order of magnitude. 


\section{SUMMARY}

This is the third volume in a series of three volumes characterizing the population of sealed sources that may become greater-than-Class C low-level radioactive waste (GTCC LLW). In Volumes 1 and 2, sealed sources possessed by specific licensees were characterized and volumes and activities estimated. In this volume, sources possessed by general licensees are discussed.

General-licensed and specific-licensed sealed sources are similar in some ways. They frequently contain similar radionuclides and levels of activities. They are both tracked by the NRC or Agreement State agencies.

General-licensed and specific-licensed sealed sources are different in other ways. Specific-licensed sources require a radiation safety officer to track the sources at the site, and they require rigorous handling standards and controls. General-licensed devices may contain sealed sources with significant amounts of radioactive material; however, the devices are designed to be safe to use without special knowledge of radiological safety practices. Those who use specific-licensed sources are required to apply for and receive the license before they receive any sources. With general-licensed sources, no physical license is exchanged; it is granted when the user receives the source.

This report defines potential GTCC (PGTCC) and GTCC sealed sources.

- PGTCC sources exceed the $10 \mathrm{CFR} 61$ Class $\mathrm{C}$ limits when the concentration of radionuclides is calculated over the source capsule. This is a conservative concentration averaging assumption in that it results in much lower activity limits than currently acceptable methods.

- $\quad G T C C$ sources exceed the Class $C$ limits when concentration averaging is implemented over the disposal container, with certain volume, density, and surface radiation restrictions. That is, of those PGTCC sources, concentration averaging removes the sources with the lowest activities and averages their radionuclide activity over the volume or mass of encapsulation media filling an entire waste container, thereby reducing the concentration to a level acceptable to a near-surface LLW disposal facility. Concentration averaging over the disposal container is a currently accepted practice. This study estimates amounts of GTCC sources based on concentration averaging limits used in a $1989 \mathrm{NRC}$ study, as explained in Appendix D of Volume 1.

In contrast to Volumes 1 and 2, this report characterizes the GTCC sources first, since those data are more easily available for sources held by general licensees. These data are then extrapolated to the number of PGTCC sources, to allow easy comparison with the data from Volumes 1 and 2.

General-licensed devices can be broken into four categories: tritium exit signs, in vitro sources, static eliminators, and measurement gauges. Of these, only a subset of the measurement gauges have sources that exceed Class C limits. Devices containing Am-241 or Cm-244 sources are most likely to become GTCC LLW after concentration averaging. For example, measurement gauges used in production processes use Am-241 sources with activities of up to $5 \mathrm{Ci}$. These devices make up the majority of devices that are GTCC and are held by general licensees. There are also $\mathrm{x}$-ray fluorescence gauges that contain sources exceeding the Class C limit for Am-241 and Cm-244.

Because general-licensed devices are considered to be relatively safe, general licensees are not closely tracked or inspected. While this attitude is changing towards a more formal and consistent contact with general licensees, the currently available information on general licensees is not adequate to give high quality estimates on the number of such devices. This uncertainty is quantified in the low and high case estimates given in this report, which span approximately an order of magnitude. 
This study estimates that there are 160,000 general-licensed PGTCC sources held by general licensees who do not also possess a specific license. The vast majority of these sources, about 140,000, are fixed gauge devices with Cs-137 sources. These sources are highly unlikely to be classified as GTCC after concentration averaging, and hence are not of much concern to DOE's GTCC LLW program.

This study estimates that there are about 16,000 GTCC devices held by general licensees; 15,000 of these contain Am-241 sources and 1,000 contain Cm-244 sources. Additionally, this study estimates that there are 1,600 GTCC devices sold to general licensees each year. However, due to a lack of available information on general licensees in Agreement States, these estimates are uncertain. Quantification of this uncertainty leads to a range of between 3,000 and 35,000 GTCC sealed sources held by general licensees, and 300 to 3,500 GTCC devices sold to general licensees each year.

\section{Recommendations}

Results presented in this volume are considerably more uncertain than in the previous two volumes. This is a direct result of the lack of available information. Significantly improved estimates are not likely until more rigid tracking of general licensees is implemented. It is recommended that these numbers and findings be revisited in a few years when more of the Agreement States have better tracking systems in place. If this recommendation is taken, it would be worthwhile to utilize a more formal survey of the Agreement States through the use of a short questionnaire.

Agreement State authorities are currently the best source of general licensee data (in their States). Manufacturers certainly have at least as good information, but are commonly unwilling to share the information for proprietary reasons. A survey of general licensees, similar to the Volume 1 survey of specific licensees, would likely not be effective since (a) the general licensee population is not well definedlists/databases of general licensees in a given State are frequently incomplete, (b) the vast majority of general licensees will not have GTCC material, and (c) because general licensees are not required to have nuclear material safety experts, they may not understand the information being requested.

\section{Extrapolations to All Licensees}

This report is the third of three volumes. Volumes 1 and 2 discuss sealed sources held by specific licensees, while this report, Volume 3, concerns sealed sources held by general licensees. These reports give estimates of the total number of PGTCC sources (those whose activity is averaged over the source capsule) and the number of GTCC sources (assumed here to be those remaining after concentration averaging has been performed over the disposal container, as explained in Appendix D of Volume 1).

Volume 1 estimates that, in 1992, the number of PGTCC sources held by specific licensees was 89,000 . The estimated 1992 number of GTCC sources is 28,400 (Volume 1 Appendix D). In Volume 2, it is estimated that 8,000 PGTCC sources are sold per year to specific licensees.

This report, Volume 3, estimates that the general licensee population possesses roughly $36 \%$ of the total 1992 number of GTCC sealed sources. Together with the GTCC sources held by specific licensees (from Volume 1), this yields about 44,000 total GTCC sources held by all licensees. The results presented in this report and in Volume 1 for GTCC sealed sources are summarized in Table ES-1.

This report estimates that the general licensee population possesses roughly $63 \%$ of the total 1992 number of PGTCC sealed sources. Together with the PGTCC sources held by specific licensees (Volume 1), this yields about 250,000 total PGTCC sources held by all licensees. The results presented in this report and in Volume 1 for PGTCC sealed sources are summarized in Table ES-2. 
For general licensees, this report extrapolates the estimated annual number of GTCC sources sold to the number of PGTCC sources sold. When those results are added to the number of PGTCC sources sold to specific licensees (from Volume 2), the resulting estimate is 24,000 PGTCC sources sold to all licensees per year. This is shown in Table ES-3. 
Table ES-1. Base case estimates of the number of GTCC sources held by specific and general licensees. Numbers rounded to two significant digits.

\begin{tabular}{|c|c|c|c|c|c|c|c|c|}
\hline Device type & Am-241 & $\mathrm{Cm}-244$ & Cs-137 & $\mathrm{Pu}-238$ & Pu-239 & $\mathrm{Pu}-241$ & $\mathrm{U}-238$ & Subtotal \\
\hline Calibration & 1,900 & 14 & 10 & 45 & 250 & 14 & - & 2,300 \\
\hline Medical & 93 & - & 10 & 一 & - & - & 24 & 130 \\
\hline Well logging & 3,700 & - & - & 一 & - & 一 & - & 3,700 \\
\hline Portable gauge & 14,000 & - & - & - & 一 & - & 一 & 14,000 \\
\hline Irradiation & 110 & - & 590 & - & - & - & - & 700 \\
\hline Fixed gauge & 16,000 & 3 & 一 & 45 & 一 & - & 一 & 16,000 \\
\hline General neutron applications & 1,300 & - & - & 110 & 460 & - & - & 1,900 \\
\hline XRF & 1,300 & 1,300 & - & 180 & - & - & 一 & 2,800 \\
\hline Other & 550 & 21 & 10 & 1,500 & 480 & 21 & 28 & 2,600 \\
\hline Subtotal & 39,000 & 1,300 & 620 & 1,900 & 1,200 & 35 & 52 & 44,000 \\
\hline
\end{tabular}


Table ES-2. Base case estimates of the number of PGTCC sources held by specific and general licensees. Numbers rounded to two significant digits.

\begin{tabular}{|c|c|c|c|c|c|c|c|c|c|c|c|c|c|}
\hline Device type & Am-241 & C-14 & $\mathrm{Cm}-244$ & Cs-137 & $\mathrm{Ni}-63$ & Np-237 & $\mathrm{Pu}-238$ & $\mathrm{Pu}-239$ & Pu-24l & Sr-90 & Tc-99 & $\mathrm{U}-238$ & Subtotal \\
\hline Calibration & 3,000 & 24 & 34 & 3,400 & 110 & 10 & 41 & 280 & 17 & 1,900 & 17 & 34 & 8,900 \\
\hline Medical & 340 & - & - & 1,200 & - & - & - & - & 一 & 24 & 3 & 28 & 1,600 \\
\hline Well logging & 4,300 & - & 一 & 2,200 & - & - & 170 & - & 3 & - & - & 一 & 6,700 \\
\hline Portable gauge & 15,000 & - & - & 110 & - & - & - & - & - & - & - & - & 15,000 \\
\hline Irradiation & 160 & - & - & 1,700 & - & - & - & - & - & 10 & 一 & 一 & 1,800 \\
\hline Fixed gauge & 17,000 & 30 & 17 & 170,000 & - & - & 3 & - & 一 & 270 & - & 一 & 190,000 \\
\hline $\begin{array}{l}\text { General neutron } \\
\text { applications }\end{array}$ & 1,500 & - & - & - & - & 一 & 110 & 530 & - & - & - & 一 & 2,100 \\
\hline $\mathrm{XRF}$ & 3,300 & - & 1,400 & 3 & - & - & 180 & - & 一 & - & - & - & 4,900 \\
\hline Other & 1,100 & 62 & 34 & 11,000 & 3,900 & 3 & 1,600 & 650 & 21 & 300 & 500 & 80 & 19,000 \\
\hline Subtotal & 46,000 & 120 & 1,500 & 190,000 & 4,000 & 13 & 2,100 & 1,500 & 41 & 2,500 & 520 & 140 & 250,000 \\
\hline
\end{tabular}


Table ES-3. Base case estimates of the number of PGTCC sealed sources sold annually to both specific and general licensees. The numbers are rounded to at most two significant digits.

\begin{tabular}{|c|c|c|c|c|c|c|c|c|c|c|c|c|c|}
\hline Device type & Am-241 & C-14 & $\mathrm{Cm}-244$ & Cs-137 & $\mathrm{Ni}-63$ & Np-237 & $\mathrm{Pu}-238$ & Pu-239 & $\mathrm{Pu}-241$ & Sr-90 & Tc-99 & $\mathrm{U}-238$ & Total \\
\hline Calibration & 290 & 2 & 3 & 330 & 11 & 1 & 4 & 30 & 2 & 190 & 2 & 3 & 860 \\
\hline Medical & 30 & 0 & 0 & 110 & 0 & 0 & 0 & 0 & 0 & 2 & 0 & 3 & 150 \\
\hline Well logging & 130 & 0 & 0 & 60 & 0 & 0 & 5 & 0 & 0 & 0 & 0 & 0 & 190 \\
\hline Portable gauge & 1,500 & 0 & 0 & 11 & 0 & 0 & 0 & 0 & 0 & 0 & 0 & 0 & 1,500 \\
\hline Irradiation & 15 & 0 & 0 & 120 & 0 & 0 & 0 & 0 & 0 & 1 & 0 & 0 & 140 \\
\hline Fixed gauge & 1,700 & 3 & 2 & 17,000 & 0 & 0 & 0 & 0 & 0 & 27 & 0 & 0 & 19,000 \\
\hline $\begin{array}{l}\text { General neutron } \\
\text { applications }\end{array}$ & 140 & 0 & 0 & 0 & 0 & 0 & 11 & 50 & 0 & 0 & 0 & 0 & 210 \\
\hline XRF & 310 & 0 & 136 & 0 & 0 & 0 & 14 & 0 & 0 & 0 & 0 & 0 & 460 \\
\hline Other & 110 & 6 & 3 & 1,100 & 370 & 0 & 15 & 60 & 2 & 30 & 40 & 8 & 1,700 \\
\hline Total & 4,200 & 12 & 140 & 19,000 & 390 & 1 & 50 & 140 & 4 & 250 & 50 & 14 & 24,000 \\
\hline
\end{tabular}




\section{CONTENTS}

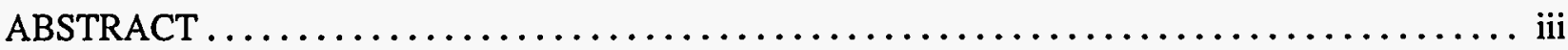

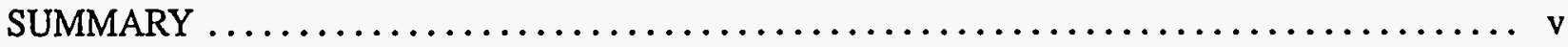

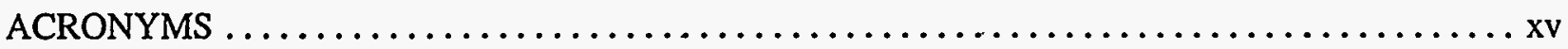

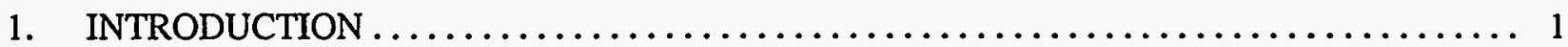

$1.1 \quad$ General Licensees $\ldots \ldots \ldots \ldots \ldots \ldots \ldots \ldots \ldots \ldots \ldots \ldots \ldots \ldots \ldots \ldots \ldots \ldots \ldots \ldots$

1.2 Estimated Number of General-Licensed Devices $\ldots \ldots \ldots \ldots \ldots \ldots \ldots \ldots \ldots \ldots 2$

2. PHONE SURVEY OF THE AGREEMENT STATES $\ldots \ldots \ldots \ldots \ldots \ldots \ldots \ldots \ldots \ldots$

2.1 Responses: Registration of General Licensees $\ldots \ldots \ldots \ldots \ldots \ldots \ldots \ldots \ldots \ldots \ldots$

2.2 Responses: Number of Licensees and Devices $\ldots \ldots \ldots \ldots \ldots \ldots \ldots \ldots \ldots, \ldots$

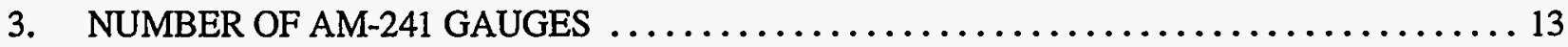

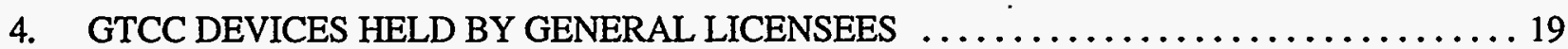

4.1 Total Number of General-Licensed, Am-241 GTCC Fixed Gauge Devices Held

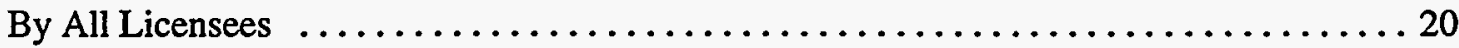

4.1.1 Reasons for Discrepancies in the Agreement State and non-Agreement State Numbers ................................. 20

4.1.2 Number of GTCC Devices Adjusted for Uncertainties $\ldots \ldots \ldots \ldots \ldots \ldots \ldots 22$

4.2 Number of GTCC General-Licensed Devices Held by General Licensees . . . . . . . . 22

4.2.1 General-Licensed Devices Observed in the Specific Licensee Survey $\ldots . . . .24$

4.2.2 Number of PGTCC and GTCC General-Licensed Devices Held by

Specific Licensees ................................... 24

4.2.3 Number of GTCC General-Licensed Devices Held by General Licensees . . . . 26

4.2.4 Number of General-Licensed PGTCC Devices Held by General Licensees . . . 28

4.3 Activity of GTCC General-Licensed Devices Held by General Licensees . . . . . . . . . . 29

4.4 Unpackaged Volume of GTCC General-Licensed Devices Held by General

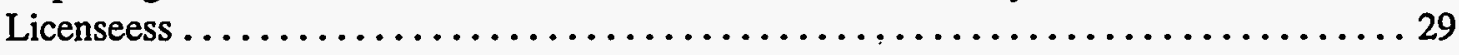

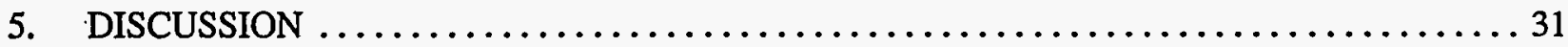

5.1 Number of General-Licensed GTCC and PGTCC Devices Sold per Year to

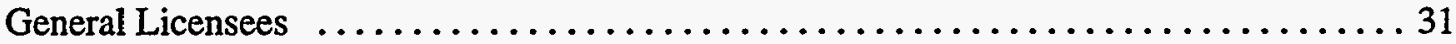

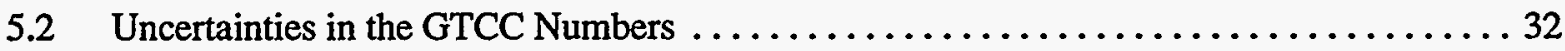

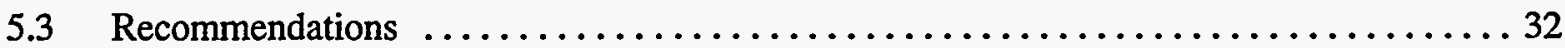

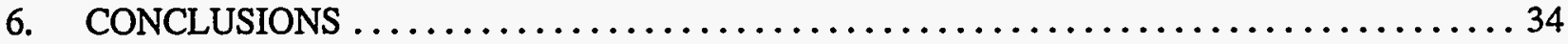

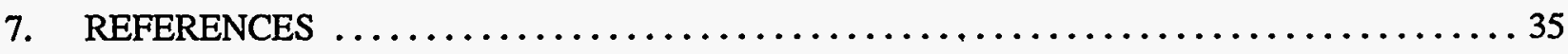




\section{FIGURES}

1. Example of the quarterly report format that distributors use to inform licensing agencies of

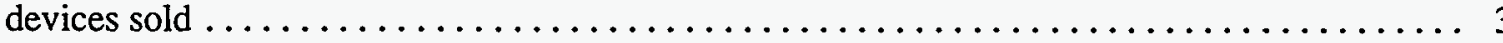

2. Regression models (with and without the California data) predicting the number of Am-241

devices from the amount of manufacturing, plotted with the observed values $\ldots \ldots \ldots \ldots 18$

\section{TABLES}

ES-1. Base case estimates of the number of GTCC sources held by specific and general

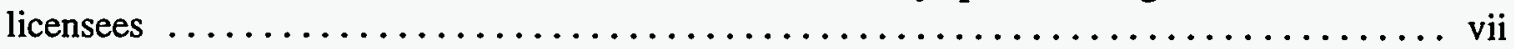

ES-2. Base case estimates of the number of PGTCC sources held by specific and general

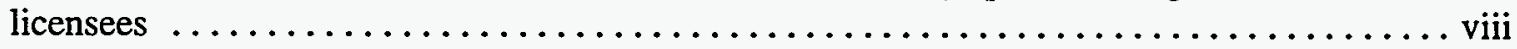

ES-3. Base case estimates of the number of PGTCC sealed sources sold annually to both

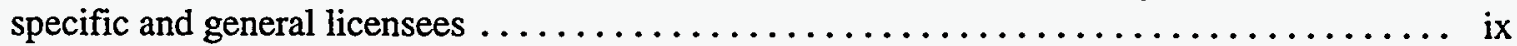

1. Estimated number of general-licensed devices held by non-Agreement State licensees

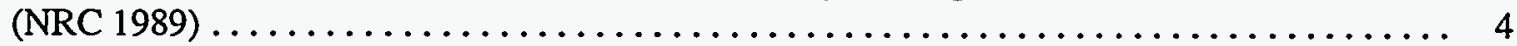

2. Brief description of general licensee tracking in the Agreement States $\ldots \ldots \ldots \ldots \ldots$

3. Summary of responses to phone calls to Agreement State licensing personnel $\ldots \ldots \ldots \ldots 10$

4. Some summary statistics of the responses of the Agreement State licensing agencies ..... 12

5. List of the amount of the gross State product due to manufacturing and the number of

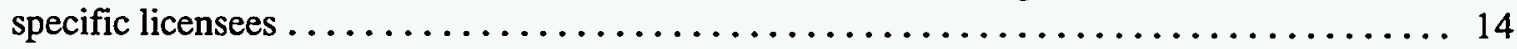

6. Correlations between responses to questions, including California data $\ldots \ldots \ldots \ldots \ldots$

7. Correlations between responses to questions, excluding California data $\ldots \ldots \ldots \ldots \ldots$

8. Gross State product due to manufacturing, and predicted number of general-licensed, Am-241 GTCC fixed gauge devices by State under the low case $\ldots \ldots \ldots \ldots \ldots \ldots \ldots$

9. License code of GTCC devices observed in ALLSO.DBF $\ldots \ldots \ldots \ldots \ldots \ldots \ldots \ldots$

10. License code of PGTCC devices observed in ALLSO.DBF $\ldots \ldots \ldots \ldots \ldots \ldots \ldots \ldots$

11. Number of general-licensed PGTCC devices held by specific licensees $\ldots \ldots \ldots \ldots \ldots$

12. Number of GTCC general-licensed devices held by specific licensees $\ldots \ldots \ldots \ldots \ldots$

13. Number of GTCC general-licensed devices held by general licensees $\ldots \ldots \ldots \ldots \ldots$

14. Number of general-licensed PGTCC devices held by general licensees $\ldots \ldots \ldots \ldots \ldots$ 
15. Average activities of GTCC and general-licensed PGTCC devices . . . . . . . . . 29

16. Total activities of general-licensed, GTCC and PGTCC devices $\ldots \ldots \ldots \ldots \ldots \ldots \ldots$

17. Unpackaged volumes of general-licensed, GTCC and PGTCC devices $\ldots \ldots \ldots \ldots \ldots$

18. Summary of the low, base, and high case estimates characterizing sources held by general

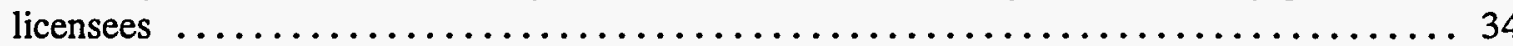




\section{ACRONYMS}

CFR Code of Federal Regulations

DOE U.S. Department of Energy

GLDB General Licensee Database

GTCC greater-than-Class C

LLW low-level radioactive waste

NRC U.S. Nuclear Regulatory Commission

PGTCC potential greater-than-Class C

TRU transuranic

XRF $\quad \mathrm{X}$-ray fluorescence 


\section{Characterization of Greater-Than-Class C Sealed Sources . Volume 2: Sealed Sources Held by General Licensees}

\section{INTRODUCTION}

By enacting the Low-Level Radioactive Waste Policy Amendments Act of 1985, the U.S. Congress made the U.S. Department of Energy (DOE) responsible for ensuring the safe disposal of greater-than-Class C (GTCC) lowlevel radioactive waste (LLW). This is the third report in a series of three reports estimating the amount of GTCC LLW material in sealed source form. The first report characterized the sources, including the number and types of sources, held by specific licensees. The second report gave additional source characterization data and estimated the number of sources produced annually. This report focuses on characterizing sources held by general licensees.

Note that the terminology for "Potential GTCC" (PGTCC) and "GTCC" devices follows that of Volumes 1 and 2:

- PGTCC sources exceed the 10 CFR 61 Class C limits when the concentration of radionuclides is calculated over the source capsule. This is a conservative concentration averaging assumption in that it results in much lower activity limits than currently acceptable methods.

- GTCC sources exceed the Class $\mathrm{C}$ limits when concentration averaging is implemented over the disposal container, with certain volume, density, and surface radiation restrictions. That is, of those PGTCC sources, concentration averaging removes the sources with the lowest activities and averages their radionuclide activity over the volume or mass of encapsulation media filling an entire waste container, thereby reducing the concentration to a level acceptable to a near-surface LLW disposal facility. Concentration averaging over the disposal container is a currently accepted practice. This study estimates amounts of GTCC sources based on concentration averaging limits used in a 1989 NRC study, as explained in Appendix D of Volume 1.

Unlike Volumes 1 and 2, this volume attempts to characterize the GTCC sources first and then extrapolate the number of PGTCC sources. The first two volumes focus almost exclusively on estimating the characteristics of PGTCC sources. Data on sources held by general licensees is limited; the most readily available data on GTCC sources held by general licensees has been for sources which will be classified as GTCC after concentration averaging is performed.

Results presented in this volume are considerably more uncertain than in the previous two volumes. This is a direct result of the lack of available information. Significantly improved estimates are not likely until more rigid tracking of general licensees is implemented.

\subsection{General Licensees}

The use of radioactive source materials can be grouped into three categories for the purpose of defining the degree of regulatory control necessary to protect public health and safety (NRC 1989). These are (a) specific licenses covering activities that require an understanding of certain radiation protection principles and procedures in order to safely possess and use the materials; (b) general licenses covering the possession and use of sources or source-device combinations that have sufficient built-in shielding and containment features to 
require no special training in radiation protection for safe use; and (c) sources and devices that are exempt from licensing, because they represent essentially no threat to public health and safety, and for which there is no particular concern over the ultimate disposal of the devices. While the Nuclear Regulatory Commission (NRC) has jurisdiction over nuclear materials licensing in some States, 28 States have opted to regulate such materials through their own regulatory agency. These States, known as Agreement States, have entered into agreements with the NRC to regulate certain by-product materials within their State. Licenses are issued by either the NRC or Agreement State regulatory offices, as explained in Volume 1.

Specific licenses are issued only to individually named persons or organizations after application to the NRC or an Agreement State. General licenses go into effect without application to the NRC or to an Agreement State, and, except in some Agreement States and for certain devices, without issuance of license documents.

Under Section 31.5 of the Code of Federal Regulations (CFR), general licenses are created for source material contained in certain measuring, gauging, illuminating, and controlling devices. The activity of source material within these devices ranges from microcuries to several curies.

There are approximately 50 vendors licensed by the NRC and 75 licensed by the Agreement States. These vendors must have a specific license authorizing them to distribute the product to general licensees. Additionally, the product must be registered through either the NRC or an Agreement State. As part of the product registration, the regulatory authority performs a safety review based on information supplied by the vendor.

Vendors must report (typically quarterly) devices transfers to the regulatory agency of the State within which the device is sent. Such reports identify

- Each general licensee by name and address

- An individual who may constitute a point of contact for the general licensee by name or position

- The type and model number of the device transferred

- The quantity and type of by-product material contained in the device.

An example report form is shown in Figure 1. These reports are the regulatory agencies' primary source of information about materials held by general licensees under their jurisdiction.

General licensees are expected to be able to use the devices safely without having radiological safety training or experience, because the general license program is predicated on the fact that safety is built into the device. General licensees are required to follow any minimum safety instructions and precautions contained on the device label, are required to have certain types of maintenance performed only by someone authorized by the NRC or an Agreement State, and may only transfer the device to a specific licensee authorized to accept the device.

\subsection{Estimated Number of General-Licensed Devices}

Over the past 5 years, the NRC has become more interested for safety reasons in the general license program. In Policy Issue SECY-89-289 (NRC 1989), the NRC identifies potential problems with the general license program and identifies possible actions to strengthen the program. In that Policy Issue, it is estimated that there are 30,000 general licensees using about 400,000 devices in non-Agreement States, and about twice that many in Agreement States. About $85 \%$ of these devices are tritium exit signs and static eliminators neither of which will be GTCC LLW.

Table 1 shows the NRC Policy Issue's estimated number of general-licensed devices in non-Agreement States. From this table, over 5,000 general-licensed, Am-241 GTCC sources are held by non-Agreement 


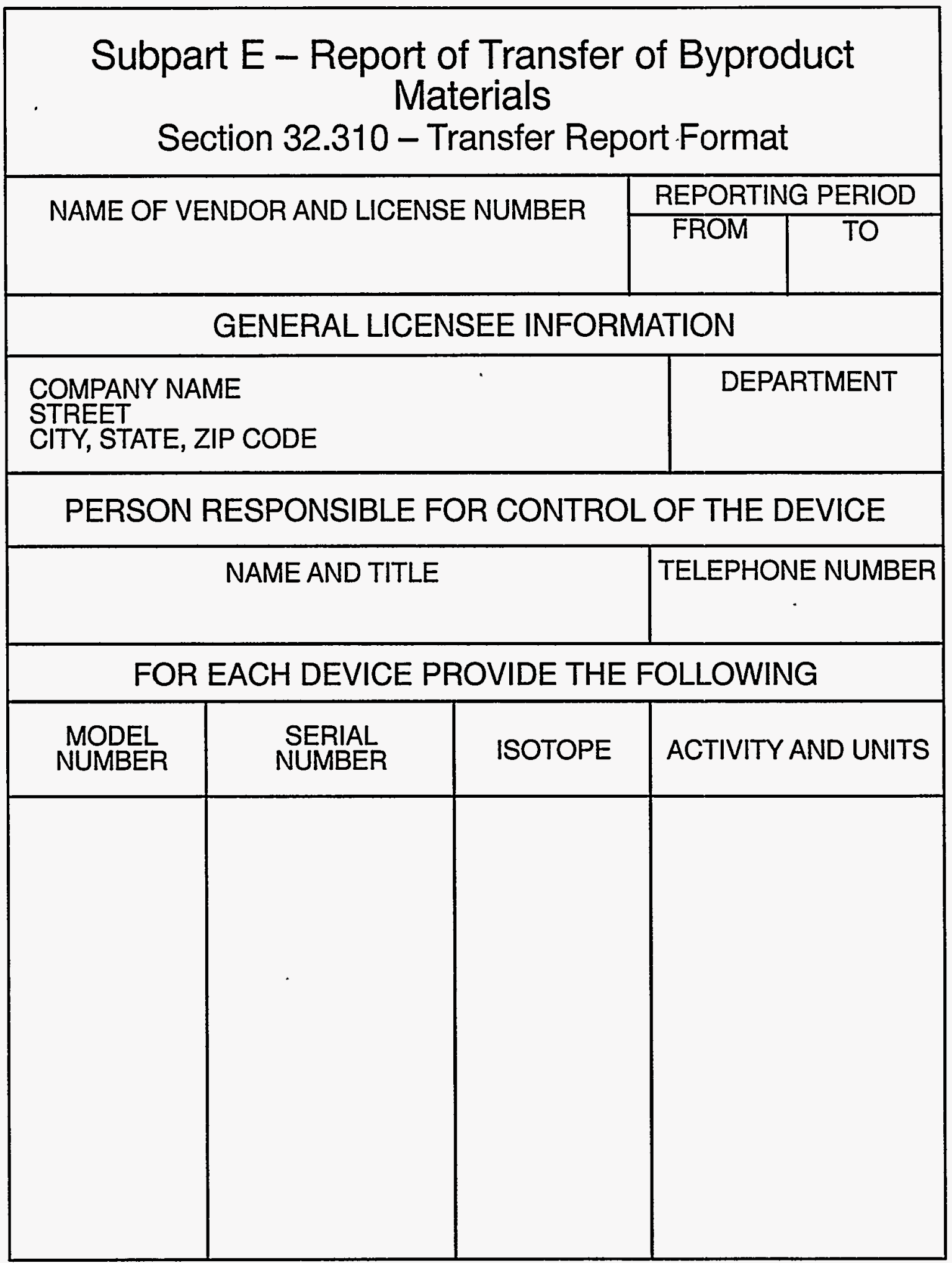

Figure 1. Example of the quarterly report format that distributors use to inform licensing agencies of devices sold. These reports are the primary source of information on the population of general licensees. 
Table 1. Estimated number of general-licensed devices held by non-Agreement State licensees (NRC 1989).

\begin{tabular}{|c|c|c|c|c|}
\hline Device type & $\begin{array}{l}\text { Isotope and } \\
\text { activity }\end{array}$ & $\begin{array}{l}\text { GTCC } \\
\text { material }\end{array}$ & $\begin{array}{l}\text { Number of } \\
\text { devices sold } \\
\text { per year }\end{array}$ & $\begin{array}{l}\text { Total number } \\
\text { of devices } \\
\text { in } 1989\end{array}$ \\
\hline Aerosol neutralizer & $\mathrm{Kr}-85(15 \mathrm{mCi})$ & No & 120 & 9,600 \\
\hline Beta backscatter gauge & $\begin{array}{l}\text { Pm-147 }(900 \mu \mathrm{Ci}) \\
\text { Tl-204 }(45 \mu \mathrm{Ci}) \\
\text { Sr-90 }(5 \mu \mathrm{Ci}) \\
\mathrm{Cs}-137(30 \mu \mathrm{Ci})\end{array}$ & $\begin{array}{l}\text { No } \\
\text { No } \\
\text { No } \\
\text { No }\end{array}$ & 800 & 7,000 \\
\hline $\begin{array}{l}\text { Electron capture detector } \\
\text { (gas chromatography) }\end{array}$ & $\mathrm{Ni}-63(15 \mathrm{mCi})$ & No & 900 & 8,000 \\
\hline Electrostatic voltmeter & $\mathrm{Ni}-63(10 \mu \mathrm{Ci})$ & No & 890 & 3,000 \\
\hline Fuel densitometer emitter & Am-241 (50 mCi) & Yes & 200 & 945 \\
\hline Gauging devices & $\begin{array}{l}\text { Am-241 (0.5-5 Ci) } \\
\text { Co-60 (0.5-1 Ci) } \\
\text { Cs-137 (0.5-4 Ci) } \\
\text { Kr-85 (0.5-1.2 Ci }) \\
\text { Sr-90 (0.5-1 Ci })\end{array}$ & $\begin{array}{l}\text { Yes } \\
\text { No } \\
\text { No } \\
\text { No } \\
\text { No }\end{array}$ & 337 & 16,000 \\
\hline Fill-level gauges & Am-241 (100 mCi) & Yes & 600 & 4,200 \\
\hline $\begin{array}{l}\text { In-flight blade inspection } \\
\text { systems }\end{array}$ & $\mathrm{Sr}-90(500 \mu \mathrm{Ci})$ & No & 200 & 1,000 \\
\hline $\begin{array}{l}\text { Liquid scintillation spectro- } \\
\text { meters }\end{array}$ & $\begin{array}{l}\text { Cs-137 }(40 \mu \mathrm{Ci}) \\
\mathrm{Ra}-226(5 \mu \mathrm{Ci})\end{array}$ & $\begin{array}{l}\text { No } \\
\text { No }\end{array}$ & 600 & 7,000 \\
\hline Self-luminous exit signs & $\mathrm{H}-3(25 \mathrm{Ci})$ & No & 20,000 & 180,000 \\
\hline Static eliminators/meters & $\begin{array}{l}\mathrm{H}-3(200 \mu \mathrm{Ci}) \\
\text { Po-210 }(167 \mathrm{mCi})\end{array}$ & $\begin{array}{l}\text { No } \\
\text { No }\end{array}$ & 80,000 & 160,000 \\
\hline $\begin{array}{l}\text { X-ray fluorescence spectro- } \\
\text { meters }\end{array}$ & $\begin{array}{l}\mathrm{Fe}-55(30 \mathrm{mCi}) \\
\mathrm{Cd}-109(3 \mathrm{mCi}) \\
\mathrm{Am}-241(10 \mathrm{mCi}) \\
\mathrm{Cm}-244(30 \mathrm{mCi})\end{array}$ & $\begin{array}{l}\text { No } \\
\text { No } \\
\text { No } \\
\text { Yes }\end{array}$ & 90 & 720 \\
\hline
\end{tabular}


State general licensees. Extrapolating to all general licensees, it is estimated that there are over 15,000 such sources. This value is about half the number of Am-241 GTCC sources estimated in Volume 1 to be held by specific licensees.

The information contained in Table 1 indicates that Am-241 and, to a lesser extent, Cm-244 sources are the only isotopes that may be GTCC LLW held by general licensees. The number of devices sold per year is based on the quarterly manufacturer/distributor reports the NRC receives. They do not reflect distributors licensed through Agreement States. The number of devices shown in Table 1 reflects only non-Agreement State licensees.

In another NRC report, Baggett and Rich (1989) estimate that there are 67,500 general-licensed GTCC sources in both Agreement States and non-Agreement States. These estimates assume concentration averaging as described in Volume 1 Appendix D, and are based upon information contained in the NRC's General License Data Base (GLDB). This database is based upon the quarterly reports of transfers that the manufacturers must submit to the NRC.

In 1992, the NRC issued a proposed rule for "Requirements Concerning the Accessible Air Gap for General-Licensed Devices" (57 FR 56287, 11/27/92). In this notice of proposed rulemaking, the NRC updated its 1989 estimates, giving 35,000 general licensees and 450,000 general-licensed devices in nonAgreement States.

While the 1989 NRC Policy Issue and 1992 proposed rulemaking estimate that there are about twice as many general licensees and devices in Agreement States, later discussions with NRC personnel indicated that they feel this to be an overestimate. ${ }^{\mathrm{a}}$ They believe the true ratio to be between 1 to 2 times the number of non-Agreement State devices and licensees. Indeed, Baggett and Rich (1989) assume a 1-to-1 correspondence in calculating their estimates.

However, the NRC acknowledges that there is a great deal of uncertainty in their Agreement State estimates. ${ }^{b}$ While they do have an extensive database of general licensees in non-Agreement States, they have little knowledge of general licensees in Agreement States.

Most recently, the NRC queried their revised GLDB to determine the number of Am-241 GTCC devices held by non-Agreement State general licensees. ${ }^{c}$ The GLDB contains data from device manufacturers' reports of sales and transfers. It was recently revised so that the data pertained only to non-Agreement State general licensees (previously it included incomplete information on Agreement State general licensees). In February 1994, the NRC queried the GLDB and found that there were 12,700 general-licensed, Am-241, GTCC devices (i.e., devices containing sources with greater than $27 \mathrm{mCi}$ activity of Am-241, as described in Appendix D of Volume 1 of this report series) held by non-Agreement State licensees. This is considered to be the most accurate data available.

In short, it appears that the population of general-licensed GTCC sources may be significant with respect to the overall number of GTCC sources. However, while the NRC does have rough estimates of the number of general-licensed GTCC sources in non-Agreement States, there is little information on those values for Agreement States. To fill this data gap, a series of phone calls were made to Agreement State radioactive materials licensing personnel. The results of these conversations are given in the following section.

a. Steven L. Baggett telephone communication with Gerald Harris, April 30, 1993.

b. Steven L. Baggett telephone communication with Gerald Harris, April 30, 1993.

c. Steven L. Baggett telephone communication with Gerald Harris, February 22, 1994. 


\section{PHONE SURVEY OF THE AGREEMENT STATES}

In January 1994, a series of phone calls were made to Agreement State radioactive materials licensing personnel. The primary purpose of the calls was to determine the number of GTCC devices held by general licensees in their States. A variety of questions were asked of each respondent. These questions were developed with three objectives in mind:

- Determine the licensing agency's degree of control and knowledge of general licensees within the Agreement State

- Help direct the respondent toward a reasonable estimate of the number of GTCC devices

- If a reasonable estimate cannot be obtained, collect information that may be used to help predict the number of GTCC devices through, for example, a statistical regression analysis.

Agreement States vary in the degree of control of general licensees. Indeed, they vary even in what devices may be maintained under a general license. Hence the initial objective was as much a scoping question as it was to determine the degree of uncertainty in the respondents' answers to the remaining questions. A State that actively tracks and inspects general licensees will likely provide better data than one that just files away the quarterly reports received from device distributors.

Since it was unlikely that the Agreement States would know how many GTCC devices were held by general licensees in their States, a series of questions were asked to help direct the respondent toward a reasonable estimate. In many cases, this strategy worked. However, in other cases, the respondent had so little knowledge of the general licensee population, that they would not even hazard a guess.

Additionally, the questions were developed to allow a statistical correlation/regression analysis. For example, if the respondent did have a good feel for the number of general licensees in the State, but did not know how many general-licensed devices there were, a relationship between the number of licensees and number of devices may be established from the remaining data. This allows estimation of that States' number of devices from their number of licensees.

The questions asked are as follows:

1. How do you track general licensees and their devices? What devices are covered under a general license?

2. How many general licensees are in your State?

3. How many general licensees would have devices with GTCC material?

4. How many devices are held under general licenses in your State?

5. How many of those devices have GTCC material?

6. What proportion of your specific licensees also maintain material under a general license?

7. Are you aware of any general licensees who have had problems disposing or transferring GTCC devices?

These are the fundamental questions that were asked of all Agreement State licensing agencies. However, there was some leeway in the way the questions were asked. For example, as discussed in the results 
section, the respondents usually had clearer ideas on the number of industrial fixed gauges than on other types of devices in their State. These gauges make up the majority of the Am-241 sources held under a general license. So the sequence of questions generally became: What proportion of general licensees have fixed gauges, and how many fixed gauge devices do they have? Of these, what proportion have Am-241?

\subsection{Responses: Registration of General Licensees}

The initial question asked of the Agreement State licensing authorities established the level of control the agency has over its general licensees. In addition to establishing the respondents' level of knowledge of general licensees, the answers also helped identify what each State covered under general licenses. This latter point is important since DOE's GTCC LLW Program will not be interested in the vast majority of general-licensed devices; in some States, those devices of interest are recommended or even required to be specifically licensed. Table 2 summarizes the general licensee tracking practices in Agreement States.

Of 28 Agreement States, 14 actively or routinely contact at least certain types of general licensees. The degree of contact ranges from a letter verifying the information sent to the agency by the device distributor to requiring the licensee to annually send the agency an itemized inventory of general-licensed devices. In some cases, the contact is only with certain subsets of the general licensee population - for example, those using medical/in vitro material (in vitro sources contain microcurie amounts of certain radionuclides and are used in clinical and laboratory tests; they are not used for brachytherapy) or gauging devices. Two of the 14 States track only in vitro sources. Most States do not track tritium (H-3) exit signs.

Licensees in 11 States are required to register with the licensing agency. This registration differs from that of specific licensees in that general licensees are not required to register until after they receive the device. Specific licensees must be registered before they receive radioactive materials under that license.

The remaining 14 Agreement States, which do not actively contact general licensees, file the device distributors' quarterly reports. Of these, five States enter the report data into an electronic database. Two States that currently do not use an electronic database are working toward creating one.

Nine Agreement States either currently charge a fee or are planning to implement one. The fees range from a one-time $\$ 50$ charge to an annual payment of $\$ 200$. The fees are used to cover administrative costs and, in some cases, costs associated with inspection.

Seven Agreement States actively inspect general-licensed facilities. However, for most of these States, it is not a priority. For example, inspectors may go to a general-licensed facility if they happen to be in the area (inspecting a specific licensee). Other States are actively engaged in inspecting all general licensees and plan to continue periodic inspections of all licensees.

Many of the respondents indicated that there needed to be more controls or awareness of general licensees. This concern can be at least partly attributable to the NRC's increased concern. The respondents noted cases of illegal transfers of devices to other general licensees and illegal disposal (or even meltdown for recycling steel) typically done out of ignorance of the regulations. Cases were consistently noted in which the licensee was surprised to be contacted by the agency about nuclear material that they were not aware they were possessing.

Two States, New York and North Dakota, are significantly different in their general licensing practices. New York has three licensing agencies. The only one that tracks licensees of concern to DOE's GTCC LLW Program is the Department of Labor. Furthermore, the Department is attempting to get all general licensees to register as specific licensees. In North Dakota, the devices of concern to DOE's GTCC LLW Program are all specific licensed. 
Table 2. Brief description of general licensee tracking in the Agreement States.

\begin{tabular}{|c|c|}
\hline State & Tracking of general licensees \\
\hline Alabama & Licensees are required to register. They are inspected, but this is low priority. \\
\hline Arizona & File quarterly reports. \\
\hline Arkansas & File quarterly reports. \\
\hline California & $\begin{array}{l}\text { Licensees with gauges must register. In the process of implementing an annual fee } \\
\text { for gauge holders. }\end{array}$ \\
\hline Colorado & They are working towards establishing a database for tracking. \\
\hline Florida & $\begin{array}{l}\text { Licensees with in vitro sources, gauging devices, or depleted } U \text { annually send item- } \\
\text { ized inventory and pay a fee. There is an inspection program. }\end{array}$ \\
\hline Georgia & Quarterly reports are input to database. Fee, excluding H-3 signs. \\
\hline Illinois & $\begin{array}{l}\text { Licensees with sources }>1 \mathrm{mCi} \text { (excluding } \mathrm{H}-3 \text { signs) must register. Licensees are } \\
\text { periodically sent questionnaires about their devices. }\end{array}$ \\
\hline Iowa & Track only in vitro sources. Considering a broader tracking system. \\
\hline Kansas & File quarterly reports. \\
\hline Kentucky & Licensees must fill out a verification note. Fee, excluding $\mathrm{H}-3$ signs. \\
\hline Louisiana & Licensees are registered and pay a one time fee. Track device serial numbers. \\
\hline Maryland & Working on creating a tracking database. \\
\hline Mississippi & Licensees are tracked; inspected about every 3 years. \\
\hline Nebraska & Licensees are registered. Fee per device location. Inspect every 5 years. \\
\hline Nevada & Quarterly reports are input to database. \\
\hline New Hampshire & Quarterly reports are input to database. \\
\hline New Mexico & File quarterly reports. Plan to begin inspecting regularly. \\
\hline New York & $\begin{array}{l}\text { Licensees are registered. Sporadic inspections. NY is trying to change all general } \\
\text { licensees to specific licensees. }^{a}\end{array}$ \\
\hline North Carolina & Licensees are registered. Inspect every 4 years. \\
\hline North Dakota & Quarterly reports are filed. All TRU sources are specific licensed. \\
\hline Oregon & In vitro and industrial gauge licensees are registered and charged a fee. \\
\hline Rhode Island & Track only in vitro sources. \\
\hline South Carolina & Quarterly reports are input to database. \\
\hline Tennessee & Licensees are tracked. Fee, excluding $\mathrm{H}-3$ signs. \\
\hline Texas & Licensees must send an acknowledgement to the Radiation Program. Fee. \\
\hline Utah & In vitro, measuring gauges, and depleted U licensees are registered. \\
\hline Washington & Quarterly reports are input to database. \\
\hline
\end{tabular}

a. New York has three different radioactive materials licensing agencies. This information reflects only the Dept. of Labor's licensing as they are responsible for industrial gauges. 


\subsection{Responses: Number of Licensees and Devices}

While all the Agreement State licensing agencies were well aware of their general license programs, they typically had considerably less knowledge about the magnitude of general licensees and their devices. This can be attributed to a number of causes:

- Historically, there has been little control or tracking of general licensees. Only recently has there been increased attention.

- Most of the tracking through registration and databases has only recently been implemented and may not have complete data.

- The degree of tracking depends upon the type of general licensees. For example, a State may know about those licensees with in vitro material, but have little knowledge of industrial gauge users.

Before asking for specific numbers, the respondents were queried as to the types of devices their general licensees possessed and which of these could become GTCC LLW. In all States, tritium exit signs were the most frequent device held under a general license, though these are typically not tracked. Most respondents also indicated large numbers of static elimination devices.

It also became clear through these initial discussions that Am-241 sources in certain gauging devices were the only major GTCC materials, though there are some X-ray fluorescence (XRF) gauges with Am-241 or Cm-244 that may be GTCC material. Fixed gauges are typically industrial gauges used in controlling manufacturing processes. While there was mention of other source and device types, the respondent would indicate that there were at most 1 or 2 of them. As such, the focus of the numerical estimates became one of getting a best estimate of the number of Am-241 fixed gauges used by general licensees in the State.

A summary of the results, along with some descriptive data (to be used in the next section) is shown in Table 3. The ability of the respondents to give numerical estimates was sparse. About $75 \%$ of the responses were given as numerical estimates. The remaining $25 \%$ of the numbers were taken directly from databases. So, while the quality of the data may be less than optimal, it is the best available within the project scope.

The number of general licensees shown in Table 3 was adjusted so as not to include tritium exit signs. Since most States do not actively track tritium signs, they did not include these licensees in their estimate of the number of general licensees. Most States that did include tritium signs in the estimate were able to estimate the proportion of general licensees with these signs, so the number was easy to adjust. In those instances in which the respondent did not know what proportion were tritium signs, the total number of general licensees was halved since this was roughly the proportion of tritium signs in other States.

The remaining data shown in Table 3 are given as stated by the respondent. The respondents had a much easier time answering the remaining questions when they focused on industrial fixed gauge licensees. Hence the responses shown in Table 3 are relative to these licensees. In most cases, the number of devices was essentially determined by estimating the average number of devices per licensee and multiplying by the estimated number of licensees.

Some descriptive statistics of the responses are shown in Table 4. Briefly, the results indicate that about $40 \%$ of the general licensees (not including tritium exit signs) have industrial fixed gauges and about $11 \%$ of the general licensees have Am-241 industrial fixed gauges. There are slightly under an average of 0.3 Am-241 fixed gauges per general licensee. 
Table 3. Summary of responses to phone calls to Agreement State licensing personnel. . $^{\mathrm{a}, \mathrm{b}}$

\begin{tabular}{|c|c|c|c|c|c|c|c|c|}
\hline State & $\begin{array}{l}\text { \# of gencral } \\
\text { licensees }\end{array}$ & $\begin{array}{l}\text { \# of fixed } \\
\text { gauge } \mathrm{GLs} s^{\mathrm{c}}\end{array}$ & $\begin{array}{l}\text { \# of Am-241 } \\
\text { fixed gauge } \\
\text { GLs }^{c}\end{array}$ & $\begin{array}{l}\text { \# of fixed } \\
\text { gauge devices }\end{array}$ & $\begin{array}{l}\text { \# of Am-241 } \\
\text { fixed gauge } \\
\text { devices }\end{array}$ & $\begin{array}{l}\text { \# of fixed gauges } \\
\text { sold per year }\end{array}$ & $\begin{array}{l}\text { \# of Am-241 } \\
\text { fixed gauges } \\
\text { sold per year }\end{array}$ & $\begin{array}{l}\% \text { of SLs } \\
\text { with GL } \\
\text { devices }^{d}\end{array}$ \\
\hline Alabama & & & & & $<50$ & & & $25 \%$ \\
\hline Arizona & & & & & & & & $2-3 \%$ \\
\hline Arkansas & 425 & & & & & & & $25 \%$ \\
\hline California & 10,000 & & 200 & & 400 & & 60 & \\
\hline Colorado & 100 & & & & & & & \\
\hline Florida & 500 & 240 & & & & & & \\
\hline Georgia & 200 & 50 & $\sim 40$ & & 100 & & & $12 \%$ \\
\hline Illinois & 800 & 400 & 100 & & & & & \\
\hline lowa & 200 & 150 & & $400-500$ & & $30-40$ & & $10 \%$ \\
\hline \multicolumn{9}{|l|}{ Kansas } \\
\hline Kentucky & 204 & 150 & & & & $40-50$ & & $5 \%$ \\
\hline Louisiana & 250 & 75 & & & & $10-12$ & & $30 \%$ \\
\hline \multicolumn{9}{|l|}{ Maryland } \\
\hline Mississippi & 100 & & $15-20$ & & $50-75$ & $4-5$ & & $2 \%$ \\
\hline Nebraska & 200 & & $25-50$ & & $25-50$ & $<5$ & & $9 \%$ \\
\hline Nevada & 225 & 20 & 2 & 40 & $<4$ & $5-10$ & & $5 \%$ \\
\hline New Hampshire & 100 & & $<10$ & & 12 & & 3 & $9 \%$ \\
\hline
\end{tabular}


Table 3. (continued).

\begin{tabular}{|c|c|c|c|c|c|c|c|c|}
\hline State & $\begin{array}{l}\text { \# of general } \\
\text { licensees }\end{array}$ & $\begin{array}{l}\text { \# of fixed } \\
\text { gauge GLs }\end{array}$ & $\begin{array}{c}\text { \# of Am-241 } \\
\text { fixed gauge } \\
\text { GLs }^{c}\end{array}$ & $\begin{array}{l}\text { \# of fixed } \\
\text { gauge devices }\end{array}$ & $\begin{array}{l}\text { \# of Am-241 } \\
\text { fixed gauge } \\
\text { devices }\end{array}$ & $\begin{array}{l}\text { \# of fixed gauges } \\
\text { sold per year }\end{array}$ & $\begin{array}{l}\text { \# of Am-241 } \\
\text { fixed gauges } \\
\text { sold per year }\end{array}$ & $\begin{array}{l}\text { \% of SLs } \\
\text { with GL } \\
\text { devices }^{\text {d }}\end{array}$ \\
\hline New Mexico & 25, & 8 & & $<20$ & & & & $2 \%$ \\
\hline New York & 300 & & & & & & & $>50 \%$ \\
\hline North Carolina & 675 & & $50-75$ & & $100-150$ & & $10-20$ & $10-20 \%$ \\
\hline North Dakota & & & 0 & & 0 & & 0 & \\
\hline Oregon & 20 & & $4-5$ & & 12 & & $<1$ & $0 \%$ \\
\hline Rhode Island & & & & & 6 & 15 & 2 & \\
\hline South Carolina & 200 & 150 & 8 & & 49 & 100 & & $3-4 \%$ \\
\hline \multicolumn{9}{|l|}{ Tennessee } \\
\hline Texas & 500 & 333 & & & & $<5$ & & $25-30 \%$ \\
\hline Utah & & 22 & & 44 & & & & $<2 \%$ \\
\hline Washington & 245 & & 30 & & 128 & & 14 & $27 \%$ \\
\hline \multicolumn{9}{|c|}{ a. Blank spaces in the table represent areas where the respondents were unable to give information. } \\
\hline \multicolumn{9}{|c|}{ b. Responses adjusted to exclude tritium exit signs. } \\
\hline \multicolumn{9}{|c|}{ c. GLs $=$ general licensees. } \\
\hline
\end{tabular}


Table 4. Some summary statistics of the responses of the Agreement State licensing agencies.

\begin{tabular}{|c|c|c|c|c|c|}
\hline Quantity & $\mathrm{N}^{\mathrm{a}}$ & Average & Std. Error & Minimum & Maximum \\
\hline Proportion of $\mathrm{GLs}^{\mathrm{b}}$ with fixed gauges & 10 & 0.406 & 0.067 & 0.044 & 0.750 \\
\hline Proportion of GLs with Am-241 gauges & 11 & 0.114 & 0.017 & 0.004 & 0.250 \\
\hline Proportion of gauge GLs with Am-241 & 4 & 0.301 & 0.075 & 0.053 & 0.800 \\
\hline \# of Am-241 gauge devices per GL & 10 & 0.286 & 0.033 & 0.009 & 0.630 \\
\hline $\begin{array}{c}\text { \# of Am-241 devices sold each year } \\
\text { per Am-241 gauge device } \\
\text { currently possessed by a GL }\end{array}$ & 6 & 0.197 & 0.013 & 0.083 & 0.333 \\
\hline \multicolumn{6}{|c|}{ a. $\mathrm{N}=$ number of responses used in calculating the summary statistics. } \\
\hline
\end{tabular}

The wide range of results, as seen by comparing the minimum and maximum shown in Table 4, is in part due to the quality of the answers, but also reflects true differences between the Agreement States. States with a relatively large proportion of their economy in industrial processes will likely have relatively more Am-241 gauges than a State in which industrial processes are not as prevalent.

The last row in Table 4, number of Am-241 devices sold each year per Am-241 gauge device currently possessed by a general licensee in the State is used later in the report to estimate the number of Am-241 devices sold each year. For example, if there are $100 \mathrm{Am}-241$ gauges currently possessed by general licensees, then $0.197 \times 100=19.7$ or about $20 \mathrm{Am}-241$ gauges sold to general licensees per year.

Since not all of the Agreement States were able to provide estimates and since the estimates that were provided were not of ideal quality, some more advanced manipulation of the data was required to get estimates of the number of GTCC devices held by general licensees. This is done in Section 3. 


\section{NUMBER OF AM-241 GAUGES}

The data provided by the Agreement States were sparse and, at best, only moderately accurate. Since not all States were able to estimate the number of GTCC devices held by general licensees, a method was devised to estimate this number. It should be emphasized that the purpose of this is to estimate the total number of GTCC devices held by general licensees in the whole country. The NRC has provided data on the numbers in non-Agreement States. That leaves the data gap of numbers of GTCC devices in Agreement States. Note that estimating the number of GTCC devices in a given State is not of interest here.

From Table 1, it is evident that Am-241 gauges make up the majority of GTCC sealed sources held by general licensees. Since the Agreement State personnel appeared to have a better impression of the number of Am-241 gauges than on most other types of devices, the total number of such gauges is analyzed separately in this section. In Section 4, the number of Cm-244 gauges and total number of GTCC devices is estimated.

The number of Am-241 gauges was given by only 12 States (excluding North Dakota, which does not assign general licenses to TRU material). Indeed, not one of the questions requiring numerical responses was answered by all 28 Agreement States, including the estimate of the number of general licensees.

To determine the number of Am-241 gauges, there needs to be a variable with complete information that is, a response for each of the 28 States. For example, if we found that the number of general licensees has a strong relationship with the number of Am-241 gauges, we still would not be able to predict the number of Am-241 gauges for all States since the number of general licensees is unknown for some States. Hence, new variables with complete data must be found.

While a number of variables were attempted, two exhibited fairly strong relationships with the number of Am-241 gauges: the number of specific licensees and the amount of the State's gross product due to manufacturing. These values are shown in Table 5. The statistical linear correlations between these variables and the telephone survey responses are shown in Table 6 . The correlation between the manufacturing and number of Am-241 fixed gauge devices is 0.9754 . The correlation between the number of specific licensees and number of Am-241 gauges is 0.953 . These are both extremely strong relationships.

However, a closer look at the data reveals that this correlation is heavily influenced by the California data. Since the California values are so much larger than those for the remaining States, it causes a strong relationship between variables.

The correlations were reevaluated after removing the California observations as shown in Table 7. This resulted in correlations between manufacturing and number of Am-241 gauges of 0.833 and between number of specific licensees and number of Am-241 gauges of 0.649.

This result is not too surprising. The general-licensed, Am-241 gauges are typically used in manufacturing processes, and hence, the amount of manufacturing in a State is likely to be a good predictor of the number of gauges. The number of specific licensees, however, may reflect other sectors of society that are not associated with fixed gauges such as hospitals or construction firms.

As such, the amount of manufacturing was used in a statistical linear regression analysis to establish the number of Am-241 gauges. By using the available number of Am-241 gauges, a regression line was fit to the data. This regression model was then used to predict the number of gauges in each Agreement State. The predicted values were then summed to get the total number of Am-241 gauges.

When the California data is included in the regression analysis, the resulting model is 
Table 5. List of the amount of the gross State product due to manufacturing and the number of specific licensees. These data are used to help predict the number of Am-241 fixed gauge devices held by general licensees in the Agreement States.

\begin{tabular}{|c|c|c|c|}
\hline State & $\begin{array}{c}\$ \\
\text { Manufacturing }^{\mathrm{a}}\end{array}$ & $\begin{array}{l}\text { \# of specific } \\
\text { licensees }\end{array}$ & $\begin{array}{c}\text { \# of Am-241 } \\
\text { fixed gauge } \\
\text { devices }\end{array}$ \\
\hline Alabama & $1.3 \times 10^{10}$ & 403 & $<50$ \\
\hline Arizona & $7.2 \times 10^{9}$ & 310 & \\
\hline Arkansas & $7.8 \times 10^{9}$ & 261 & \\
\hline California & $9.8 \times 10^{10}$ & 2,235 & 400 \\
\hline Colorado & $7.6 \times 10^{9}$ & 418 & \\
\hline Florida & $1.9 \times 10^{10}$ & 1,093 & \\
\hline Georgia & $2.2 \times 10^{10}$ & 501 & 100 \\
\hline Illinois & $4.2 \times 10^{10}$ & 788 & \\
\hline Iowa & $9.2 \times 10^{9}$ & 200 & \\
\hline Kansas & $7.9 \times 10^{9}$ & 335 & \\
\hline Kentucky & $1.2 \times 10^{10}$ & 393 & \\
\hline Louisiana & $9.7 \times 10^{9}$ & 509 & \\
\hline Maryland & $9.1 \times 10^{9}$ & 521 & \\
\hline Mississippi & $8.7 \times 10^{9}$ & 320 & $50-75$ \\
\hline Nebraska & $3.7 \times 10^{9}$ & 172 & $25-50$ \\
\hline Nevada & $9.3 \times 10^{8}$ & 160 & $<4$ \\
\hline New Hampshire & $4.8 \times 10^{9}$ & 110 & 12 \\
\hline New Mexico & $1.9 \times 10^{9}$ & 243 & \\
\hline New York & $6.0 \times 10^{10}$ & 1,269 & \\
\hline North Carolina & $3.2 \times 10^{10}$ & 571 & $100-150$ \\
\hline North Dakota & $6.2 \times 10^{8}$ & 139 & 0 \\
\hline Oregon & $8.2 \times 10^{9}$ & 303 & 12 \\
\hline Rhode Island & $3.7 \times 10^{9}$ & 75 & 6 \\
\hline South Carolina & $1.2 \times 10^{10}$ & 320 & 49 \\
\hline Tennessee & $1.8 \times 10^{10}$ & 550 & \\
\hline Texas & $4.9 \times 10^{10}$ & 1,724 & \\
\hline Utah & $4.0 \times 10^{9}$ & 170 & \\
\hline Washington & $1.3 \times 10^{10}$ & 178 & 128 \\
\hline
\end{tabular}


Table 6. Correlations between responses to questions, including California data. ${ }^{\mathrm{a}}$

\begin{tabular}{|c|c|c|c|c|c|c|}
\hline & $\begin{array}{l}\text { \# of Am-241 } \\
\text { fixed gauge } \\
\text { devices }\end{array}$ & $\begin{array}{c}\text { \# of } \\
\text { fixed gauge } \\
\text { devices }\end{array}$ & $\begin{array}{c}\text { \# of Am-241 } \\
\text { fixed gauge } \\
\text { GLs }^{b}\end{array}$ & $\begin{array}{l}\text { \# of fixed } \\
\text { gauge GLs }\end{array}$ & $\begin{array}{c}\text { \# of } \\
\text { general } \\
\text { licensees }\end{array}$ & $\begin{array}{c}\text { \# of } \\
\text { specific } \\
\text { licensees }\end{array}$ \\
\hline \$ Manufacturing & $\begin{array}{c}0.9754 \\
11 \\
0.000\end{array}$ & $\begin{array}{c}0.9893 \\
3 \\
0.093\end{array}$ & $\begin{array}{c}0.9776 \\
11 \\
0.000\end{array}$ & $\begin{array}{c}0.8746 \\
10 \\
0.001\end{array}$ & $\begin{array}{c}0.7684 \\
20 \\
0.000\end{array}$ & $\begin{array}{c}0.9268 \\
21 \\
0.000\end{array}$ \\
\hline $\begin{array}{r}\text { \# of specific } \\
\text { licensees }\end{array}$ & $\begin{array}{c}0.9530 \\
11 \\
0.000\end{array}$ & $\begin{array}{c}0.0957 \\
3 \\
0.939\end{array}$ & $\begin{array}{c}0.9583 \\
11 \\
0.000\end{array}$ & $\begin{array}{c}0.7292 \\
10 \\
0.017\end{array}$ & $\begin{array}{c}0.7005 \\
20 \\
0.001\end{array}$ & \\
\hline $\begin{array}{r}\text { \# of general } \\
\text { licensees }\end{array}$ & $\begin{array}{c}0.9272 \\
10 \\
0.000\end{array}$ & $\begin{array}{c}-0.0603 \\
3 \\
0.962\end{array}$ & $\begin{array}{c}0.8931 \\
11 \\
0.000\end{array}$ & $\begin{array}{c}0.8114 \\
10 \\
0.004\end{array}$ & & \\
\hline $\begin{array}{l}\text { \# of fixed gauge } \\
\text { GLs }\end{array}$ & $\begin{array}{c}0.1850 \\
3 \\
0.882\end{array}$ & $\begin{array}{c}0.9994 \\
3 \\
0.022\end{array}$ & $\begin{array}{c}0.8605 \\
4 \\
0.140\end{array}$ & & & \\
\hline $\begin{array}{l}\text { \# of Am-241 } \\
\text { fixed gauge } \\
\text { GLs }\end{array}$ & $\begin{array}{c}0.9698 \\
10 \\
0.000\end{array}$ & $\begin{array}{c}\mathrm{NA}^{\mathrm{c}} \\
1 \\
\mathrm{NA}\end{array}$ & & & & \\
\hline $\begin{array}{c}\text { \# of fixed gauge } \\
\text { devices }\end{array}$ & $\begin{array}{c}\text { NA } \\
1 \\
\text { NA }\end{array}$ & & & & & \\
\hline $\begin{array}{l}\text { a. The first line gi } \\
\text { tions; the third lin } \\
\text { the true correlatio } \\
\text { b. GL = general lice } \\
\text { c. } \mathrm{NA} \text { = correlation }\end{array}$ & $\begin{array}{l}\text { the estimated } \\
\text { the probabilit } \\
\text { zero. } \\
\text { estimable due }\end{array}$ & $\begin{array}{l}\text { correlation cc } \\
\text { of observing }\end{array}$ & $\begin{array}{l}\text { fficient. The } \\
\text { correlation th }\end{array}$ & $\begin{array}{l}\text { econd line } \\
\text { s large (or l }\end{array}$ & $\begin{array}{l}\text { es the nur } \\
\text { er) when }\end{array}$ & $\begin{array}{l}\text { rof obser } \\
\text { assumed t }\end{array}$ \\
\hline
\end{tabular}


Table 7. Correlations between responses to questions, excluding California data. ${ }^{\mathrm{a}}$

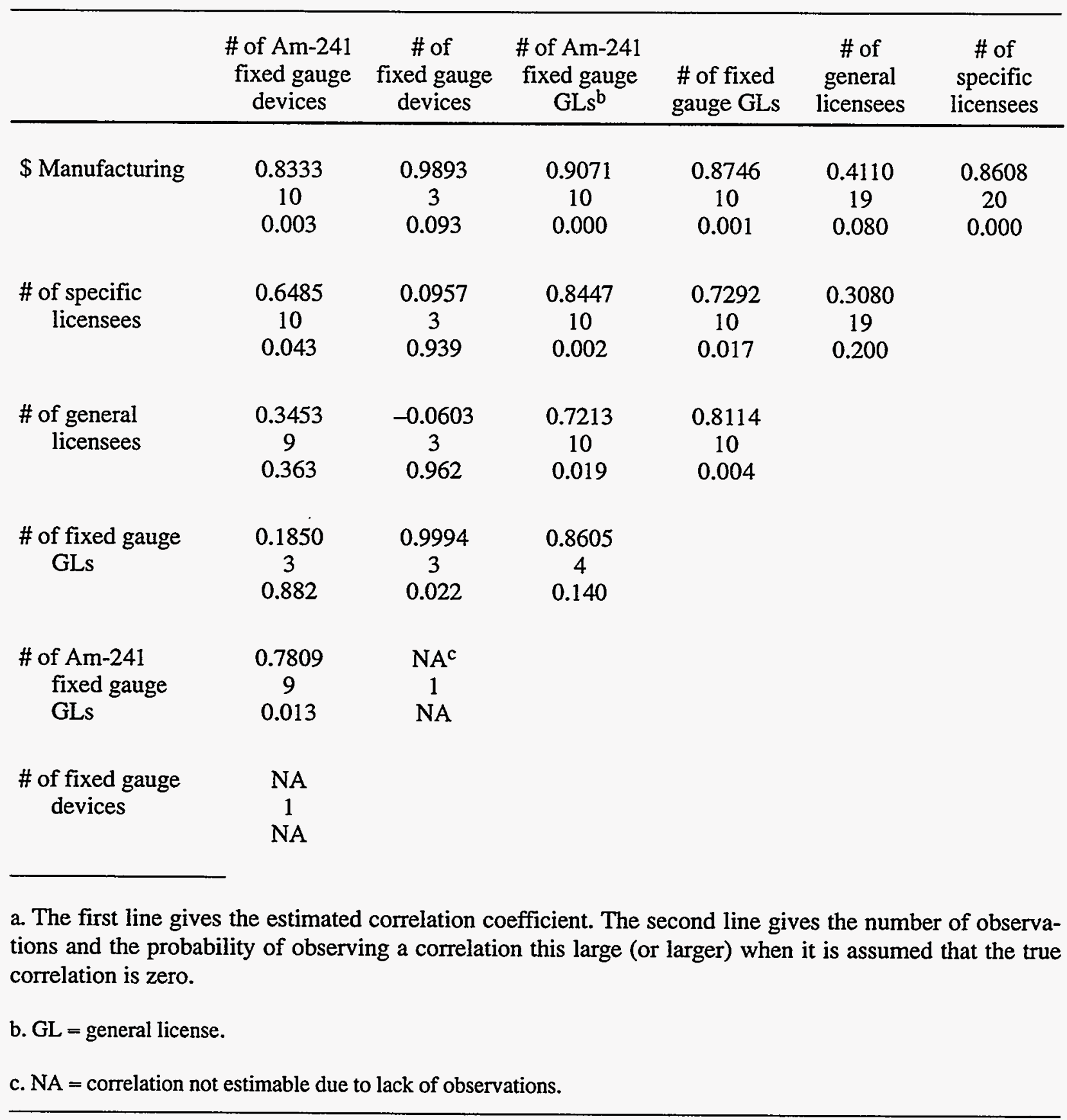


\# Am-241 devices $=11.4+(0.0040 \times$ Manufacturing- $\$)$,

where the coefficients of 11.4 and 0.004 are estimated by least squares analysis of the data. After summing over the predicted values for each Agreement State, the estimate of the total number of Am-241 devices in Agreement States is 2,250 . When the California data is not included in the regression analysis, the resulting model is

\# of Am-241 devices $=9.5+(0.0042 \times$ Manufacturing- $\$)$

and, after summing over the predicted values for each Agreement State, the total number of devices is 2,300 . Figure 2 shows the two models fit to the data.

As can be seen from Figure 2 and the previously cited results, inclusion of the California data in the regression analysis has little effect on the model and prediction. Based on the California licensing agency's level of knowledge, it is believed that their estimate of the number of Am-241 gauges is fairly accurate. As such, the California data will be included in the model.

Hence, the predicted number of Am-241 devices held by general licensees in the Agreement States is 2,250 . 


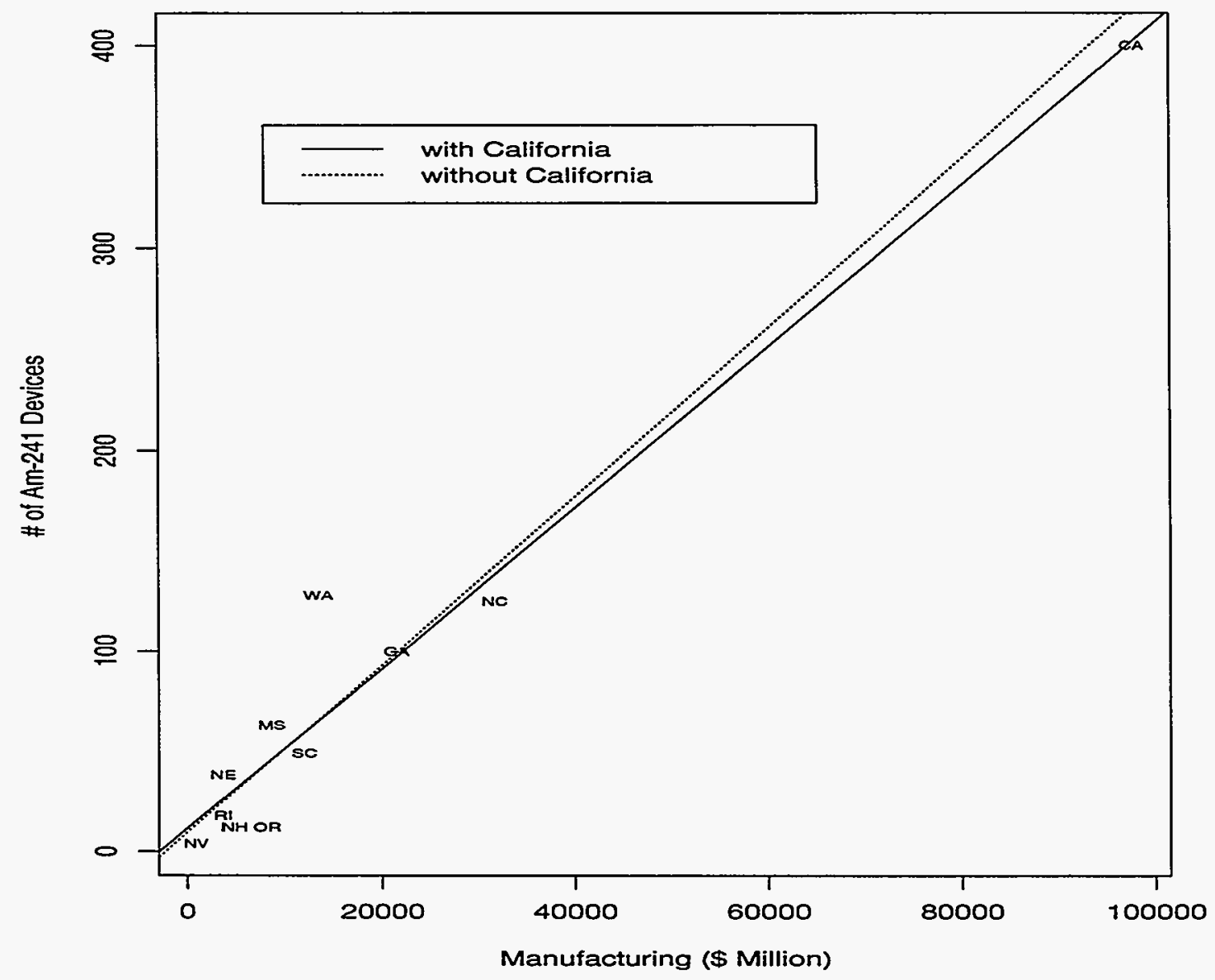

Figure 2. Regression models (with and without the California data) predicting the number of Am-241 devices from the amount of manufacturing, plotted with the observed values. 


\section{GTCC DEVICES HELD BY GENERAL LICENSEES}

In the previous section, the number of general-licensed, Am-241 fixed gauge devices held by Agreement State licensees is estimated to be 2,250. This estimate includes general-licensed devices held by both licensees with specific licenses and those without specific licenses. Volume 1 characterizes the sources held by specific licensees, including both general-licensed and specific-licensed devices. Hence, it is necessary to determine the number of general-licensed devices held by both Agreement State and non-Agreement State licensees, and to adjust these values for those general-licensed devices held by specific licensees (which are already accounted for in the Volume 1 estimates).

In this section, the following quantities are derived.

- The number of general-licensed GTCC devices held by licensees who do not possess a specific license.

- The number of general-licensed PGTCC devices held by licensees who do not possess a specific license.

- The activity of general-licensed PGTCC devices held by licensees who do not possess a specific license.

- The unpackaged volume of general-licensed PGTCC devices held by licensees who do not possess a specific license.

The extrapolations made in this chapter rely upon information derived from the ALLSO.DBF and SSD.DBF databases. The ALLSO.DBF database contains the results of the surveys of specific licensees, documented in Volume 1. The SSD.DBF database contains information from the NRC's Sealed Source and Device Registry.

When a device is registered by the NRC, the design is reviewed to assess the safety of the device. If the device design is determined to be inherently safe, it is assigned a status of general-licensed device. If the design requires external safety controls, it is assigned a status of specific-licensed device. There are also devices that, depending upon the exact configuration, could fall into either status; these devices are considered by the NRC to be "both" a general and specific-licensed device.

The device's license status determines the type of radioactive materials license a company or individual must have in order to possess the device. A specific-licensed device requires the company purchasing the device to have a specific license. A general-licensed device does not require the purchasing company to have a specific license. A specific licensee may purchase a general-licensed device, typically without modification to their specific license. A licensee without a specific license, however, may not purchase a specific-licensed device.

By crossing the information contained in the ALLSO.DBF and SSD.DBF databases, a characterization of the general-licensed devices held by specific licensees can be made. The ALLSO.DBF database contains manufacturer and model numbers of devices held by specific licensees. The SSD.DBF database contains information about the type of license required to possess a given manufacturer's device model. By linking the two databases, the general-licensed devices observed in the survey of specific licensees can be distinguished from the specific licensed devices.

If it is assumed that the PGTCC and GTCC general-licensed devices held by specific licensees are similar to those held by general licensees, then the survey results on general-licensed devices may be used to extrapolate from the GTCC Am-241 fixed gauge results derived in Section 3 and 4.1. 


\subsection{Total Number of General-Licensed, Am-241 GTCC Fixed Gauge Devices Held By All Licensees}

In much of the previous sections, the focus was on estimating the number of Am-241 GTCC fixed gauge devices held by radioactive materials licensees in Agreement States. In this section, the previous results are combined with the data on NRC's general-licensed devices to get an overall estimate of the total number of Am-241 GTCC fixed gauge devices held by licensees.

From Section 3, it is estimated that there are 2,250 general-licensed, Am-241 GTCC devices held by licensees in the Agreement States.

During February 1994, the NRC tabulated the number of Am-241 devices with activities of more than 27 $\mathrm{mCi}$ held by general licensees under their jurisdiction. They found 12,700 such devices represented in their General Licensee Database (GLDB). This number is somewhat higher than the data in Table 1, which indicates on the order of 8,000 general-licensed, Am-241 GTCC gauges. Certainly this difference is in part due to sales over the last 4 to 5 years.

There are 28 Agreement States and 22 non-Agreement States. One might therefore simply assume that the ratio of general-licensed, Am-241 GTCC fixed gauge devices in Agreement States to those in nonAgreement States would be about 28:22; yet the estimates give a ratio of approximately 1:5.

\subsubsection{Reasons for Discrepancies in the Agreement State and non-Agreement State Numbers}

There are some reasons why a discrepancy from the simple assumption might exist, summarized in the following list and discussed in detail thereafter:

- The Agreement State numbers would appear to be subject to more uncertainty than the non-Agreement State estimates, which are based on a well-maintained database.

- The Agreement States often have stricter licensing policies than the non-Agreement States. Material that may be possessed under a general license in a nonAgreement State may require a specific license in an Agreement State.

- In order to ease record keeping, Agreement States commonly have specific licensees maintain general-licensed material under their specific license.

- There is likely a small degree of inaccuracy in the NRC's GLDB estimates. Specifically, the NRC's GLDB is based on device manufacturers' quarterly reports. As such, it does not reflect devices that may have been returned to the manufacturer or transferred to an appropriate specific licensee.

4.1.1.1 Agreement State Estimates Are Not Based on Hard Data. The Agreement State data are subject to more uncertainty than the NRC data. In the past, general-licensed material has not generated much attention from regulatory agencies. Tracking of general-licensed material has not been a priority of these agencies. As such, many of the Agreement State responses were "best guesses." The NRC data, however, is based on a well-maintained database.

The Agreement State estimates may be biased low for a couple of reasons. Since many of the estimates were made extemporaneously, they may reflect only recent information that the agency has received, say for 
only the last four or five years, since these will be most clear in a respondent's mind. Similarly, the estimates may be biased only towards devices that are actively used, since licensees are likely more conscious of these devices for maintenance and inspection.

However, there is a high degree of consistency in the Agreement State results, which imparts them with a degree of validity. Assuming that the NRC results are correct, there is a consistent and large bias in the 12 independent Agreement State estimates of the number of Am-241 gauges. In particular, even those Agreement States that have been actively tracking general-licensed materials and do have well-maintained databases gave estimates that were not consistent with the NRC results, but were consistent with the remaining Agreement States.

The degree to which this may impact the Agreement State results ranges from no impact to roughly a three-fold underestimation.

4.1.1.2 Stricter Licensing Policies in Agreement States. Some Agreement States implement stricter regulations than those of the non-Agreement States. More specifically, a device that is general-licensed in a non-Agreement State may require a specific license in an Agreement State. The clearest example of this is in the Agreement State of North Dakota, which does not allow Am-241 fixed gauges to be held under a general license - such devices require a specific license.

The impact of this would be that an Agreement State licensee would have on average fewer generallicensed devices than a non-Agreement State general licensee.

\subsubsection{Maintenance of General License Material Under a Specific License. Some} Agreement States are asking their specific licensees to maintain general-licensed material under their specific licenses. Presumably this reduces paperwork and improves tracking and inspection of devices in the State. General-licensed devices held under a specific license may not have been considered in estimates from the Agreement States.

However, for those States that do implement a general license fee, this approach may not be cost effective. When general-licensed material is maintained under a specific license, the license fee is typically not increased (otherwise there would be negative incentive for the licensee to comply with the request). If a State does charge a fee to general licensees, maintenance of material under a specific license may allow the licensee to by-pass the general license fee.

Due to the interactive nature of the questioning, this concern should not significantly impact the results. When it was identified that a State did allow maintenance of general-licensed material under a specific license, the respondent was asked to include these devices in their estimates.

\subsubsection{Accuracy of the NRC's General Licensee Database. Independent of the}

Agreement State estimates, there is no reason to doubt the validity of the NRC estimates. In fact, the GLDB from which their estimates were drawn was recently revised to more accurately reflect what general-licensed devices are held by non-Agreement State licensees.

Since GLDB records are based on manufacturers' reports, there are likely devices in the database that are no longer in use and have been returned to the manufacturer or transferred to another specific licensee. However, unless those devices have either had their sealed sources disposed of or recycled, these devices should be and are included in the estimates.

As such, the impact of possible inaccuracies in the GLDB are minor at best. The possible impact is that the NRC estimates are slightly inflated. 


\subsubsection{Number of GTCC Devices Adjusted for Uncertainties}

Based on the uncertainties discussed in Section 4.1.1, the initial estimates of general-licensed, Am-241 GTCC fixed gauge devices held by radioactive material licensees are adjusted to give low, base, and high case estimates. Essentially, the low case estimates are based solely on the Agreement State results (after extrapolating to non-Agreement States); the base case estimates are based on combining the Agreement State results with the NRC GLDB results; the high case estimates are based on the NRC GLDB results (after extrapolating to Agreement States).

4.1.2.1 Low Case Estimate. Under the low case estimate, it is assumed that the estimates of the Agreement State general-licensed, Am-241 GTCC fixed gauge devices given in Section 3 are accurate. This assumption implies that the linear regression model relating the number of general-licensed, Am-241 GTCC fixed gauge devices to the gross State product due to manufacturing also holds for non-Agreement States. The model is

\# Am-241 devices $=11.4+(0.0040 \times$ Manufacturing- $\$)$.

The gross State product due to manufacturing and predicted number of general-licensed, Am-241 GTCC fixed gauge devices for all 50 States and Washington, D.C. are shown in Table 8. The low case estimate of the number of general-licensed, Am-241 GTCC fixed gauge devices held by all licensees is 3,878, or approximately 4,000 .

4.1.2.2 Base Case Estimate. Under the base case estimate, it is assumed that the estimates given in Section 3 for Agreement States are accurate and that the estimates from the NRC GLDB are accurate for non-Agreement States. Hence, the base case estimate of the number of general-licensed, Am-241 GTCC fixed gauge devices held by all licensees is $2,250+12,700=14,950$ or approximately 15,000 .

4.1.2.3 High Case Estimate. Under the high case estimate, it is assumed that the estimates from the NRC GLDB for non-Agreement States are also accurate for Agreement States after adjusting for differences in manufacturing rates between the two. The gross State product due to manufacturing in non-Agreement States is (in 1989) $\$ 339$ billion. In Agreement States, it is $\$ 485$ billion. The ratio of the two gross State products due to manufacturing is 1.43 . Hence, the high case estimate of the number general-licensed, Am-241 GTCC fixed gauge devices held by all licensees is $12,700+1.43(12,700)=$ 30,865 , or approximately 31,000 .

\subsection{Number of GTCC General-Licensed Devices Held by General Licensees}

The low, base, and high case estimates of the number of Am-241, GTCC, general-licensed devices given in Section 4.1 include devices held by specific licensees. Because devices held by specific licensees are already discussed in Volume 1, the estimates given in Section 4.1 must be adjusted so as to include only devices held by licensees without a specific license. Further, the results given in Section 4.1 must be extrapolated to include PGTCC sources and other isotope and device type combinations to allow comparison with specific licensee estimates given in Volumes 1 and 2.

To explain how these estimates were derived, the results from linking the ALLSO.DBF and the SSD.DBF databases are described. This linking results in a characterization of general-licensed devices 
Table 8. Gross State product due to manufacturing, and predicted number of general-licensed, Am-241 GTCC fixed gauge devices by State under the low case.

\begin{tabular}{|c|c|c|c|c|c|}
\hline State & $\begin{array}{l}\text { G.S.P. due to } \\
\text { manufacturing } \\
\left(\times \$ 10^{6}\right)^{\mathrm{a}}\end{array}$ & $\begin{array}{l}\text { Predicted } \\
\text { \# of fixed } \\
\text { gauge devices }\end{array}$ & State & $\begin{array}{l}\text { G.S.P. due to } \\
\text { manufacturing } \\
\left(\times \$ 10^{6}\right)^{\mathrm{a}}\end{array}$ & $\begin{array}{c}\text { Predicted } \\
\text { \# of fixed } \\
\text { gauge devices }\end{array}$ \\
\hline $\mathrm{AL}$ & 13,000 & 63 & $\mathrm{AK}$ & 980 & 15 \\
\hline $\mathrm{AZ}$ & 7,200 & 40 & $\mathrm{AR}$ & 7,800 & 43 \\
\hline $\mathrm{CA}$ & 98,000 & 402 & $\mathrm{CO}$ & 7,600 & 42 \\
\hline $\mathrm{CT}$ & 17,000 & 80 & $\mathrm{DE}$ & 3,300 & 25 \\
\hline $\mathrm{DC}$ & 1,000 & 16 & FL & 19,000 & 88 \\
\hline GA & 22,000 & 97 & HI & 1,000 & 15 \\
\hline ID & 2,100 & 20 & II & 42,000 & 181 \\
\hline $\mathbb{I N}$ & 25,000 & 113 & IA & 9,200 & 48 \\
\hline $\mathrm{KS}$ & 7,900 & 43 & KY & 13,000 & 62 \\
\hline LA & 9,700 & 50 & ME & 3,700 & 26 \\
\hline $\mathrm{MD}$ & 9,100 & 48 & MA & 25,000 & 112 \\
\hline MI & 48,000 & 201 & $\mathrm{MN}$ & 16,000 & 75 \\
\hline MS & 8,700 & 46 & MO & 19,000 & 87 \\
\hline $\mathrm{MT}$ & 880 & 15 & $\mathrm{NE}$ & 3,700 & 26 \\
\hline $\mathrm{NV}$ & 930 & 15 & $\mathrm{NH}$ & 4,800 & 31 \\
\hline $\mathrm{NJ}$ & 30,000 & 133 & NM & 1,900 & 19 \\
\hline $\mathrm{NY}$ & 60,000 & 251 & $\mathrm{NC}$ & 32,000 & 138 \\
\hline $\mathrm{ND}$ & 620 & 14 & $\mathrm{OH}$ & 51,000 & 217 \\
\hline $\mathrm{OK}$ & 7,100 & 40 & OR & 8,200 & 44 \\
\hline $\mathrm{PA}$ & 41,000 & 74 & $\mathrm{RI}$ & 3,700 & 26 \\
\hline $\mathrm{SC}$ & 12,000 & 59 & SD & 980 & 15 \\
\hline TN & 18,000 & 84 & TX & 49,000 & 206 \\
\hline UT & 4,000 & 27 & VT & 2,000 & 19 \\
\hline VA & 19,000 & 86 & WA & 13,000 & 65 \\
\hline WV & 3,500 & 25 & WI & 21,000 & 97 \\
\hline WY & 330 & 13 & Total $b$ & 824,000 & 3,878 \\
\hline
\end{tabular}


held by specific licensees (who responded to the survey described in Volume 1). These results are then extrapolated to all specific licenses, by using. results from Volume 1. Finally, the extrapolated results are used to adjust the estimates given in Section 4.1 to get the number of GTCC devices held by general licensees.

Note that the term "general licensee" will be used throughout this section to indicate a licensee who has one or more general-licensed devices but does not have a specific license.

\subsubsection{General-Licensed Devices Observed in the Specific Licensee Survey}

Device models in the survey responses contained in ALLSO.DBF were linked to their corresponding registrations in the SSD.DBF database. This allowed assignment of the license code of devices in the survey responses. The license code can be "general," "specific," or "both." The "general" license code for a device means the device may be purchased without having a specific license. A device with a "specific" license code requires a specific license for purchase. A device with a license code of "both" may require a specific license depending upon the purchased configuration of the device.

Recall from Section 2.2 that the only GTCC general-licensed devices in significant numbers are Am-241 fixed gauges, Am-241 XRF gauges, and Cm-244 XRF gauges. Additionally, from Table 1 and from $10 \mathrm{CFR} 31$, the general-licensed PGTCC devices in significant numbers also include Cs-137 and Sr-90 fixed gauges.

From Appendix D of Volume 1, the concentration averaging GTCC limit for TRUs is $27 \mathrm{mCi}$. By applying this cutoff limit to the ALLSO.DBF results and then linking to the SSD.DBF file, the breakdown of license codes by specific licensees is achieved for devices which will be GTCC after concentration averaging. There are 598 Am-241 GTCC fixed gauges in ALLSO.DBF; of these, 496 can be linked to the Registry. Similarly, there are $81 \mathrm{Am}-241$ GTCC XRF gauges, of which 47 have been linked to license codes. And of the $68 \mathrm{Cm}-244 \mathrm{GTCC}$ XRF gauges, 65 have been linked to license codes.

Table 9 breaks down the GTCC devices in the ALLSO.DBF by license code. General-licensed devices account for $35 \%, 27 \%$ are specific-licensed devices, and $38 \%$ could be either general or specific-licensed devices.

For PGTCC sources, the following linkage rates were achieved. Five-hundred forty-three of the 662 PGTCC Am-241 fixed gauge devices in ALLSO.DBF were assigned a license code. Similarly, 8,097 of 8,617 Cs-137 PGTCC fixed gauge devices, 8 of 33 Sr-90 PGTCC fixed gauge devices, 129 of 200 Am-241 PGTCC XRF devices, and 67 of 70 Cm-244 PGTCC XRF devices observed in ALLSO.DBF were assigned license codes.

Table 10 breaks down the PGTCC devices in the ALLSO.DBF by license code. Eight percent of these devices are general-licensed devices, $24 \%$ are specific-licensed devices, and $68 \%$ could be either general or specific-licensed devices.

\subsubsection{Number of PGTCC and GTCC General-Licensed Devices Held by Specific Licensees}

From the results given in Section 4.2.1 of this volume and Table B-1 of Volume 1, estimates of the number of PGTCC and GTCC general-licensed devices held by specific licensees can be made. Table B-1 of Volume 1 gives the estimated number of PGTCC devices held by specific licensees. Tables 9 and 10 provide estimates on the proportions of those (Volume 1 Table B-1) devices that are general-licensed and are GTCC. Multiplying the Table B-1 base case result by the proportion that are general-licensed devices 
Table 9. License code of GTCC devices observed in ALLSO.DBF.

\begin{tabular}{|c|c|c|c|c|c|c|c|c|}
\hline \multirow[b]{2}{*}{ Device type } & \multirow[b]{2}{*}{ Isotope } & \multicolumn{2}{|c|}{ General } & \multicolumn{2}{|c|}{ Specific } & \multicolumn{2}{|c|}{ Both } & \multirow[b]{2}{*}{ Total } \\
\hline & & Count & $\%$ & Count & $\%$ & Count & $\%$ & \\
\hline Fixed gauge & Am-241 & 180 & 36 & 104 & 21 & 212 & 43 & 496 \\
\hline \multirow[t]{2}{*}{ XRF } & Am-241 & 13 & 28 & 28 & 59 & 6 & 13 & 47 \\
\hline & $\mathrm{Cm}-244$ & 22 & 34 & 33 & 51 & 10 & 15 & 65 \\
\hline Total & & 215 & 35 & 165 & 27 & 228 & 38 & 608 \\
\hline
\end{tabular}

Table 10. License code of PGTCC devices observed in ALLSO.DBF.

\begin{tabular}{lcrrrrrrrr}
\hline & & \multicolumn{2}{c}{ General } & \multicolumn{2}{c}{ Specific } & \multicolumn{2}{c}{ Both } & \\
\cline { 3 - 7 } Device type & Isotope & \multicolumn{1}{c}{ Count } & $\%$ & Count & $\%$ & Count & $\%$ & Total \\
\hline \multirow{3}{*}{ Fixed gauge } & Am-241 & 181 & 33 & 115 & 21 & 247 & 46 & 543 \\
& Cs-137 & 420 & 5 & 1,910 & 24 & 5,767 & 71 & 8,097 \\
& Sr-90 & 1 & 12 & 7 & 88 & 0 & 0 & 8 \\
XRF & Am-241 & 36 & 28 & 81 & 63 & 12 & 9 & 129 \\
& Cm-244 & 24 & 36 & 33 & 49 & 10 & 15 & 67 \\
\cline { 3 - 7 } & & & & & & & & & \\
Total & & 662 & 8 & 2,146 & 24 & 6,036 & 68 & 8,844 \\
\hline
\end{tabular}

gives an estimate of the number of general-licensed PGTCC devices held by specific licensees. By then multiplying this latter estimate by the proportion of general-licensed sources that are also GTCC, one gets an estimate of the number of general-licensed GTCC devices held by specific licensees.

In determining the proportion of general-licensed devices observed in Tables 9 and 10, it is not obvious how to handle the devices that can be either general or specific-licensed devices. Since this is an uncertain quantity, it is used to define the low, base, and high cases. Under the low case, $75 \%$ of the "Both" status devices held by specific licensees are assumed to be general-licensed; under the base case, it is 50\%; and under the high case, it is $25 \%$.

An explanation is in order here, since at first glance these assumptions about dividing up the "Both" status devices appear backwards: more general-licensed devices are assigned to the low case than the high case. Keep in mind that these are estimates of the number of general-licensed devices held by specific licensees. Overall, the goal is to estimate the number of general-licensed devices held by general licensees. This is accomplished by subtracting out the number of general-licensed devices held by specific licensees from the estimates given in Section 4.1. Hence, a larger estimated number of general-licensed devices held by specific licensees will result in a smaller estimated number of general-licensed devices held by general licensees. 
It is difficult to assess the validity of this apportioning of the "Both" status devices. However, it is generally less expensive to maintain a device under a general license since the general license fee, if any, is less than the specific license fee. It would therefore seem reasonable to assume that more than $50 \%$ of the "Both" status devices are maintained under a general license. As such, there is some reason to believe that the apportionment is conservative for the base and high cases since it will result in fewer general-licensed devices held by specific licensees and more general-licensed devices held by general licensees.

The resulting numbers of general-licensed PGTCC devices held by specific licensees are shown in Table 11. As an example calculation, consider the low case Am-241 fixed gauges. From Table B-1 of Volume 1, there are 2,278 PGTCC Am-241 fixed gauge devices held by specific licensees. From Table 10, there are 543 PGTCC Am-241 fixed gauge devices observed in the specific licensee survey (for which a registration was found in SSD.DBF). The calculation becomes:

$2,278 \times \frac{(0.75 \times 247)+181}{543}=1,536$.

Calculation of the number of GTCC general-licensed devices held by specific licensees takes the results from Table 11 and multiplies them by the proportion of general-licensed devices that are GTCC. Continuing the low case Am-241 fixed gauge example, from Table 10 there are 181 general-licensed and 247 "both" licensed PGTCC Am-241 fixed gauge devices. And from Table 9 there are 180 general-licensed and 212 "both" licensed GTCC Am-241 fixed gauge devices. Then the number of low case Am-241 general-licensed fixed gauge devices held by specific licensees is:

$$
1,536 \times \frac{(0.75 \times 212)+180}{(0.75 \times 247)+181}=1,422
$$

Results of the GTCC calculations are shown in Table 12.

\subsubsection{Number of General-Licensed GTCC Devices Held by General Licensees}

Results from Sections 4.1.2 and 4.2.2 are now used to determine the number of GTCC general-licensed devices held by licensees who do not have a specific license. Section 4.1.2 presents estimates of the number of general-licensed, Am-241 GTCC fixed gauge sources held by all licensees. Section 4:2.2 presents estimates of the number of general-licensed PGTCC and GTCC devices held by specific licensees.

A key assumption in the calculations made in this and following sections is that the proportions of GTCC general-licensed devices and isotopes held by general licensees are similar to those held by specific licensees. While there is little evidence to support or falsify this assumption, it would seem reasonable to assume that manufacturers would have similar types of devices, whether they have a specific license or not. In any case, this is the best that can be done with the current data.

It should be emphasized, though, that the assumption is only made for PGTCC and GTCC devices. Devices that are not GTCC would very likely differ between specific and general licensees. For example, about $50 \%$ of the general-licensed devices are tritium exit signs, which cannot be GTCC devices.

To calculate the number of general-licensed, GTCC devices held by general licensees, the number of Am-241 general-licensed GTCC fixed gauge devices held by specific licensees (given in Table 12) are subtracted from the number of general-licensed, Am-241 GTCC fixed gauge devices held by all licensees (given in Section 4.1.2). The result is the number of Am-241 general-licensed GTCC fixed 
Table 11. Number of general-licensed PGTCC devices held by specific licensees.

\begin{tabular}{|c|c|c|c|c|c|}
\hline Device type & Isotope & $\begin{array}{c}\text { Table B-1 } \\
\text { result }^{\mathrm{a}}\end{array}$ & Low & Base & High \\
\hline \multirow[t]{3}{*}{ Fixed gauge } & Am-241 & 2,278 & 1,536 & $\cdot 1,277$ & 1,018 \\
\hline & Cs-137 & 29,649 & 17,376 & 12,097 & 6,817 \\
\hline & Sr-90 & 114 & 14 & 14 & 14 \\
\hline \multirow[t]{2}{*}{$\mathrm{XRF}$} & Am-241 & 688 & 240 & 224 & 208 \\
\hline & $\mathrm{Cm}-244$ & 241 & 113 & 104 & 95 \\
\hline Total & & & 19,279 & 13,716 & 8,152 \\
\hline \multicolumn{6}{|c|}{ a. Number of PGTCC devices held by specific licensees, from Volume 1.} \\
\hline Device type & Isotope & Low & & Base & High \\
\hline Fixed gauge & Am-241 & 1,422 & & 1,199 & 977 \\
\hline \multirow[t]{2}{*}{$\mathrm{XRF}$} & Am-241 & 93 & & 85 & 77 \\
\hline & $\mathrm{Cm}-244$ & 106 & & 97 & 88 \\
\hline Total & & 1,621 & & 1,381 & 1,142 \\
\hline
\end{tabular}

gauge devices held by general licensees. This results in a low case estimate of $2,456(3,878-1,422)$ such devices. The base case estimate is $13,760(14,959$ - 1,199) devices. And the high case estimate is 29,888 $(30,865$ - 977) such devices.

By the assumption that the proportion of GTCC device types and isotopes are the same for specific and general licensees, the results from Table 12 may be used to estimate the number of GTCC devices held by general licensees for Am-241 and Cm-244 XRF devices. For example, under the low case, there are 1,422 Am-241 GTCC fixed gauges and 93 Am-241 GTCC XRF devices held by specific licensees. The estimate for the number of Am-241 GTCC XRF gauges held by general licensees is then

$2,456 \times \frac{93}{1,422}=161$

The results of these calculations are shown in Table 13. 
Table 13. Number of general-licensed GTCC devices held by general licensees.

\begin{tabular}{lrrrr}
\hline & & & & \\
Device type & Isotope & Low & Base & High \\
\hline \multirow{2}{*}{ Fixed gauge } & & & & \\
XRF & Am-241 & 2,456 & 13,760 & 29,888 \\
& Am-241 & 161 & 975 & 2,356 \\
& Cm-244 & 183 & 1,113 & 2,692 \\
\cline { 3 - 5 } Total & & & & 34,936 \\
\hline
\end{tabular}

\subsubsection{Number of General-Licensed PGTCC Devices Held by General Licensees}

To allow comparison with the PGTCC results of Volumes 1 and 2, an estimate is needed of the number of PGTCC sources held by general licensees. Therefore, under the assumption that the proportion of PGTCC to GTCC general-licensed devices held by general licensees is similar to that for specific licensees, the results from Tables 11,12 , and 13 can be used to estimate the number of general-licensed transuranic PGTCC devices held by general licensees. This is done by multiplying the number of general-licensed GTCC devices held by general licensees (Table 13) by the ratio of PGTCC to GTCC general-licensed devices held by specific licensees (given in Tables 11 and 12). For example, the calculation for the low case Am-241 fixed gauge devices is

$2,456 \times \frac{1,536}{1,422}=2,653$.

Under the assumption that the proportions of general-licensed device types held by general licensees is similar to that for specific licensees, the results from Tables 11,12 , and 13 can be used to estimate the number of general-licensed PGTCC devices with Cs-137 and Sr-90 held by general licensees. This is done by multiplying the number of general-licensed Am-241 PGTCC fixed gauge devices held by general licensees by the ratio of Cs-137 (or Sr-90) to general-licensed Am-241 PGTCC devices held by specific licensees. For example, the calculation for the low case $\mathrm{Cs}-137$ fixed gauge devices is

$2,653 \times \frac{17,376}{1,536}=30,012$.

The results of these calculations are shown in Table 14.

Table 14. Number of general-licensed PGTCC devices held by general licensees.

\begin{tabular}{lcrrr}
\hline Device type & Isotope & Low & Base & High \\
\hline \multirow{2}{*}{ Fixed gauge } & & & & \\
& Am-241 & 2,653 & 14,655 & 31,142 \\
& Cs-137 & 30,012 & 138,827 & 208,541 \\
XRF & Sr-90 & 24 & 161 & 428 \\
& Am-241 & 415 & 2,569 & 6,364 \\
& Cm-244 & 195 & 1,193 & 2,906 \\
\cline { 3 - 5 } Total & & & & 249,381 \\
\hline
\end{tabular}




\subsection{Activity of General-Licensed PGTCC and GTCC Devices Held by General Licensees}

Characterization of the source activities of general-licensed PGTCC and GTCC devices held by general licensees is based on the survey results of specific licensees. As discussed in Section 4.2, survey responses were assigned license codes from the NRC's Sealed Source and Device Registry. Those records coded "G" (general license) or " $B$ " (both general and specific license) are included in the activity calculations. Records coded "S" (specific license) are excluded. The "both" sources are included because it is unknown which of these sources are held by general licensees. Since these sources are more likely to have larger activities than the " $G$ " coded sources, inclusion of these records in the calculations is conservative.

Summary statistics for the general-licensed PGTCC and GTCC devices observed in the survey results are shown in Table 15. The mean activity calculations depended upon whether the observed activities were normally or lognormally distributed. Only observations with valid activities were used (assessment of valid activities is discussed in Section 4.1 of Volume 1).

To get estimates of the total activity of general-licensed devices, the average activities were simply multiplied by the number of devices shown in Tables 13 and 14 for the GTCC and PGTCC, respectively. The total activity results are shown in Table 16.

\subsection{Unpackaged Volume of General-Licensed PGTCC and GTCC Devices Held by General Licensees}

Estimates of the volume of PGTCC and GTCC general-licensed devices held by general licensees are found by multiplying the number of sources (shown in Tables 13 and 14) by the appropriate source capsule volume. From Volume 1, the fixed gauge sources are assumed to have capsule volumes of $3 \mathrm{~cm}^{3}$ and the XRF source capsules are assumed to be $0.5 \mathrm{~cm}^{3}$. Note that the volumes are of the unpackaged sources; they do not include the device volume nor the waste packaging volume. The results are shown in Table 17.

Table 15. Average activities of GTCC and general-licensed PGTCC devices.

\begin{tabular}{|c|c|c|c|c|c|c|}
\hline GTCC & Device type & Isotope & Distribution $^{\mathrm{a}}$ & $\begin{array}{c}\text { \# of } \\
\text { observations }\end{array}$ & $\begin{array}{l}\text { Mean } \\
(\mathrm{mCi})\end{array}$ & $\begin{array}{l}\text { Std. Dev. } \\
\text { (mCi) }\end{array}$ \\
\hline \multirow[t]{5}{*}{ PGTCC } & Fixed gauge & Am-241 & $\mathrm{N}$ & 428 & 410 & 423 \\
\hline & & Cs-137 & $\mathrm{L}$ & 6,187 & 231 & 399 \\
\hline & & Sr-90 & NA & 1 & 45 & $\mathrm{NA}$ \\
\hline & XRF & Am-241 & $\mathrm{N}$ & 40 & 17 & 18 \\
\hline & & $\mathrm{Cm}-244$ & $\mathrm{~L}$ & 34 & 76 & 77 \\
\hline \multirow[t]{3}{*}{ ACA GTCC } & Fixed gauge & Am-241 & $\mathrm{N}$ & 392 & 447 & 424 \\
\hline & $\mathrm{XRF}$ & Am-241 & $\mathrm{N}$ & 11 & 39 & 21 \\
\hline & & $\mathrm{Cm}-244$ & $\mathrm{~L}$ & 32 & 79 & 73 \\
\hline
\end{tabular}


Table 16. Total activities of general-licensed GTCC and PGTCC devices.

\begin{tabular}{|c|c|c|c|c|c|}
\hline GTCC & Device type & Isotope & $\begin{array}{l}\text { Low } \\
\text { (Ci) }\end{array}$ & $\begin{array}{c}\text { Base } \\
(\mathrm{Ci}) \\
\end{array}$ & $\begin{array}{l}\text { High } \\
(\mathrm{Ci})\end{array}$ \\
\hline \multirow[t]{6}{*}{ PGTCC } & \multirow[t]{3}{*}{ Fixed gauge } & $A m-241$ & 1,114 & $6,151^{a}$ & $13,360^{\mathrm{a}}$ \\
\hline & & Cs-137 & 6,933 & 32,069 & 48,173 \\
\hline & & Sr-90 & 1 & 7 & 19 \\
\hline & \multirow[t]{2}{*}{$\mathrm{XRF}$} & Am-241 & 7 & 44 & 108 \\
\hline & & $\mathrm{Cm}-244$ & 15 & 91 & 221 \\
\hline & \multicolumn{2}{|l|}{ Total } & 8,070 & 38,362 & 61,881 \\
\hline \multirow[t]{4}{*}{ GTCC } & Fixed gauge & Am-241 & 1,098 & 6,151 & 13,360 \\
\hline & \multirow[t]{2}{*}{$\mathrm{XRF}$} & Am-241 & 6 & 38 & 92 \\
\hline & & $\mathrm{Cm}-244$ & 14 & 88 & 213 \\
\hline & \multicolumn{2}{|l|}{ Total } & 1,118 & 6,277 & 13,665 \\
\hline
\end{tabular}

Table 17. Unpackaged volumes of general-licensed GTCC and PGTCC devices.

\begin{tabular}{|c|c|c|c|c|c|}
\hline GTCC & Device type & Isotope & $\begin{array}{l}\text { Low } \\
\left(\mathrm{cm}^{3}\right)\end{array}$ & $\begin{array}{l}\text { Base } \\
\left(\mathrm{cm}^{3}\right)\end{array}$ & $\begin{array}{l}\text { High } \\
\left(\mathrm{cm}^{3}\right)\end{array}$ \\
\hline \multirow[t]{6}{*}{ PGTCC } & Fixed gauge & Am-241 & 7,959 & 43,965 & 93,426 \\
\hline & & Cs-137 & 90,036 & 416,481 & 625,623 \\
\hline & & Sr-90 & 72 & 483 & 1,284 \\
\hline & $\mathrm{XRF}$ & Am-241 & 207 & 1,285 & 3,182 \\
\hline & & $\mathrm{Cm}-244$ & 98 & 596 & 1,453 \\
\hline & Total & & 98,372 & 462,810 & 724,968 \\
\hline \multirow[t]{4}{*}{ GTCC } & Fixed gauge & Am-241 & 7,368 & 41,280 & 89,664 \\
\hline & $\mathrm{XRF}$ & Am-241 & 81 & 487 & 1,178 \\
\hline & & $\mathrm{Cm}-244$ & 91 & 557 & 1,346 \\
\hline & Total & & 7,540 & 42,324 & 92,188 \\
\hline
\end{tabular}




\section{DISCUSSION}

In this section, some miscellaneous topics are briefly discussed. Section 5.1 estimates the number of general-licensed devices sold to general licensees per year. In Section 5.2, limitations on the general licensee results are discussed. And in Section 5.3, some recommendations on future work are given.

\subsection{Number of General-Licensed GTCC and PGTCC Devices Sold per Year to General Licensees}

Agreement State materials licensing personnel were asked to provide estimates on the number of gauges sold to general licensees in their States within a given year. They were also asked for the more specific estimate of the number of Am-241 gauges and Cm-244 gauges sold in a given year. Six States gave estimates of the number of Am-241 devices sold per year and nine States gave estimates of the number of gauges (using any isotope) sold per year. Of these, only one State provided estimates of both the number of gauges and number of Am-241 gauges sold per year.

On the other hand, six States provided data on both the number of Am-241 gauges currently held by general licensees and on the number of Am-241 gauges sold per year. On average, for each Am-241 gauge possessed by a general licensee, there are 0.2 Am-241 gauges sold (see Table 4). The correlation between the number of Am-241 gauges currently possessed and the number of Am-241 gauges sold per year was over 0.99 . This indicates that the number of Am-241 gauges possessed by licensees is a strong predictor of the number of Am-241 gauges sold per year.

Table 1 provides data on sales to non-Agreement State general licensees. From Table 1, there are 200 Am-241 fuel densitometer emitters and $600 \mathrm{Am}-241$ fill-level gauges sold per year. Additionally, assuming the gauging devices are uniformly distributed over the five isotopes listed in Table 1 (so that $20 \%$ are Am-241) and the XRF gauges are uniformly distributed over the four isotopes (so that $25 \%$ are $\mathrm{Cm}-244$ ), then there are an additional 90 GTCC devices sold of these types. On average, for each GTCC device in possession of a non-Agreement State licensee, there are $(200+600+90) / 13,000 \approx 0.07$ GTCC devices sold per year.

Based on these two results, an estimate of 0.1 GTCC device sold per GTCC device possessed is reasonable. Then the estimated number of GTCC general-licensed devices sold to general licensees each year is $0.1 \times 2,800 \approx 300$ for the low case, $0.1 \times 15,848 \approx 1,600$ for the base case, and $0.1 \times 34,936 \approx 3,500$ for the high case.

Assuming that PGTCC devices are sold at a similar rate to the GTCC devices, an estimate of 0.1 PGTCC device sold per PGTCC device possessed is reasonable. Hence, it is estimated that the number of PGTCC devices sold to general licensees per year is $0.1 \times 33,299=3,300$ for the low case, $0.1 \times 157,405=15,700$ for the base case, and $0.1 \times 249,381=24,900$ for the high case. A breakdown of the base case number of PGTCC sources sold to general licensees in a given year results in estimates of $1,500 \mathrm{Am}-241$ fixed gauges, $14,000 \mathrm{Cs}-137$ fixed gauges, $160 \mathrm{Sr}-90$ fixed gauges, $260 \mathrm{Am}-241 \mathrm{XRF}$ gauges, and $120 \mathrm{Cm}-244 \mathrm{XRF}$ gauges.

Estimates of the number of PGTCC devices sold to specific licensees are given in Volume 2. These estimates were in part developed from information provided by manufacturers. By comparing these values to the current inventory of PGTCC devices held by specific licensees given in Volume 1, it is determined that there are 0.09 PGTCC devices sold to specific licensees for each PGTCC device possessed by specific licensees. This is in substantial agreement with the independent estimate used here of 0.1 GTCC and PGTCC devices sold to general licensees for each GTCC and PGTCC device possessed by general licensees. 


\subsection{Uncertainties in the GTCC Numbers}

The nearly order-of-magnitude difference in the low and high case estimates is a direct reflection of the uncertainties in the available information. The two major sources of uncertainty are the lack of available data and the disagreement between the NRC and Agreement State estimates. Additionally, many of the results are based on assumptions that, while they appear to be reasonable, cannot be verified.

There are significant limitations in the available data on general licensees. In some States, there is no active tracking of general licensees aside from receipt of the manufacturers' quarterly reports. The databases maintained by some Agreement States have typically only been recently implemented and are not yet complete. Additionally, some State licensing personnel indicated concern over the completeness of the manufacturers' quarterly reports upon which the general licensee databases are based. They noted situations in which they found general-licensed devices at sites for which they had not been notified.

There are significant discrepancies in the NRC estimates of the number of general-licensed GTCC sources and what the Agreement States believe. The NRC estimates are based on information contained in their database of general licensees. Many of the Agreement State estimates were essentially educated guesses. However, when the Agreement State personnel produced more defensible estimates, these estimates still indicated a significantly smaller number than the NRC estimates. No doubt, part of this discrepancy is due to the fact that many of the Agreement States are more restrictive in what materials they allow to be maintained under a general license.

Since the Agreement State responses were typically extemporaneous estimates, they may be heavily biased to recent data, i.e., the last 4 or 5 years of manufacturers' quarterly reports.

The problem with assuming that the Agreement State responses are the ones in error is that they are consistent with each other. That is, of the 28 Agreement States, 12 gave independent estimates of the number of Am-241 fixed gauges held by general licensees in their States. These 12 estimates were consistently smaller than what would be expected based on the NRC data. Further, these 12 estimates did show a high degree of correlation with the amount of manufacturing occurring in the State. This correlation would be expected since fixed gauges are most commonly used in manufacturing applications.

The estimated number of PGTCC devices given in Sections 4 and 5 are based on an important assumption. In order to derive the numbers, assumptions are made about the ratio of the number of PGTCC devices to the number of GTCC devices. The ratios are based on general-licensed device data from specific licensees. While it seems reasonable to assume that the general and specific licensees would have similar generallicensed manufacturing devices, no empirical data is available to support or refute the assumption.

The order of magnitude difference between the low and high case estimates is a direct result of these uncertainties. Until more complete and higher quality data become available, the uncertainties and range of estimates will remain fairly large.

\subsection{Recommendations}

Results presented in this volume are considerably more uncertain than in the previous two volumes. This is a direct result of the lack of available information. Significantly improved estimates are not likely until more rigid tracking of general licensees is implemented. It is recommended that these numbers and findings be revisited in a few years when more of the Agreement States have better tracking systems in place. If this recommendation is taken, it would be worthwhile to utilize a more formal survey of the Agreement States through the use of a short questionnaire. 
Agreement State authorities are currently the best source of general licensee data (in their States). Manufacturers certainly have at least as good information, but are commonly unwilling to share the information for proprietary reasons. A survey of general licensees, similar to the Volume 1 survey of specific licensees, would likely not be effective since (a) the general licensee population is not well defined - lists/ databases of general licensees in a given State are frequently incomplete, (b) the vast majority of general licensees will not have GTCC material, and (c) because general licensees are not required to have nuclear material safety experts, they may not understand the information being requested. 


\section{CONCLUSIONS}

General licenses are granted to companies upon receipt of certain devices that do not require special knowledge of radioactive materials principles in order to use the device safely. General-licensed devices can be roughly broken into four categories: tritium exit signs, in vitro sources, static eliminators, and measurement gauges. Of these, only a subset of the measurement gauges have sources that exceed GTCC limits.

Certain measurement gauges used in production processes use Am-241 sources with activities of up to $5 \mathrm{Ci}$. These devices make up the majority of devices that are GTCC and are held by general licensees. There are also XRF gauges which contain sources exceeding the GTCC limit for Am-241 and Cm-244.

It is estimated that there are 160,000 general-licensed PGTCC sources held by general licensees who do not also possess a specific license. The vast majority of these sources, about 140,000, are fixed gauge devices with Cs- 137 sources. These sources are highly unlikely to be classified as GTCC, and hence are not of much concern to DOE's GTCC LLW program.

However, it is estimated that there are 16,000 sources that exceed GTCC limits (after concentration averaging as described in Appendix $D$ of Volume 1) and are held by general licensees. Of these, 15,000 are Am-241 sources and 1,000 are $\mathrm{Cm}-244$ sources.

Because general-licensed devices are considered to be relatively safe, general licensees are not closely tracked or inspected. While this attitude is changing towards a more formal and consistent contact with general licensees, the currently available information on general licensees is not adequate to give high quality estimates on the number of such devices. This uncertainty is quantified in the low and high case estimates given in this report (and summarized in Table 18), which span approximately an order of magnitude.

Table 18. Summary of the low, base, and high case estimates characterizing sources held by general licensees.

\begin{tabular}{lrrr}
\hline \multicolumn{1}{c}{ Quantity } & Low & Base & High \\
\hline & & & \\
Number of PGTCC sources & 33,000 & 160,000 & 250,000 \\
Activity of PGTCC sources (Ci) & 8,100 & 38,000 & 62,000 \\
Unpackaged volume of PGTCC & 0.10 & 0.46 & 0.72 \\
$\quad$ sources (m ${ }^{3}$ ) & & & \\
Number of GTCC sources & 2,800 & 16,000 & 35,000 \\
Activity of GTCC sources (Ci) & 1,100 & 6,300 & 14,000 \\
Unpackaged volume of GTCC & 0.01 & 0.04 & 0.09 \\
$\quad$ sources $\left(\mathrm{m}^{3}\right)$ & & & \\
\hline
\end{tabular}




\section{REFERENCES}

Baggett, Steven, and Thomas Rich. 1989, Above Class C SourcelDevice In'entory Survey, U.S. Nuclear Regulatory Commission, 1989.

Harris, Gerald and Anna Griffel, 1994, Characterization of Greater-Than-Class C Low-Level Radioactive Waste Sealed Sources Volume 2: Sealed Source Characterization and Future Production, DOE/ LLW-163, National Low-Level Waste Management Program, EG\&G Idaho, Inc., September 1994.

Harris, Gerald, 1994, Characterization of Greater-Than-Class C Low-Level Radioactive Waste Sealed Sources Volume 1:Sealed Sources Held by Specific Licensees, DOE/LLW-163, National Low-Level Waste Management Program, EG\&G Idaho, Inc., September 1994.

U.S. Department of Commerce, 1989, Statistical Abstract of the United States, 1989.

NRC, 1989, "Staff Initiatives on the General License Program," Policy Issue SECY-89-289, U.S. Nuclear Regulatory Commission, September 14, 1989. 